\title{
Acute Phase Proteins: Ferritin and Ferritin Isoforms
}

\author{
Alida Maria Koorts and Margaretha Viljoen \\ University of Pretoria \\ South Africa
}

\section{Introduction}

Ferritin is a positive acute phase reactant, exhibiting increased levels in blood during the acute phase response. Nevertheless, the precise role of ferritin as an acute phase reactant remains to be clarified. As for other acute phase proteins, ferritin is produced and secreted by hepatocytes. However, ferritin is also produced and secreted by other cell types, including macrophages and cancer cells. Many isoforms of ferritin (isoferritins) are found in the body, depending on the H-subunit to L-subunit ratio in the ferritin protein shell. The subunit composition of ferritin molecules is a major determinant of the functional properties of the ferritin isoforms. Expression of ferritin and its subunits is governed by the amount of metabolically available iron, the presence of oxidative stress and both pro- and antiinflammatory cytokines. Ferritin as an acute phase reactant is well known for its intracellular iron sequestration and storage abilities during immune activation (Weiss \& Goodnough, 2005). This function is of high importance for protection of the body against microbial proliferation, oxidative damage, inflammation and cancer. Although the regulation of iron appears to be a primary function of ferritin in both normal conditions and during the acute phase response, other functions, beyond the control of iron bio-availability, have also been described. Although more investigations are required in order to clarify the precise role of ferritin as an acute phase reactant, this chapter shows a synopsis on the present knowledge on ferritin during the acute phase response. In the first part of this chapter (2-4), the processes of iron sequestration, storage and release by the ferritin molecule, the significance of the presence of isoferritins, and the regulation of the expression of ferritin by iron are described. In the next section (5) changes with diseases, and possible significance of extracellular (plasma) ferritin is discussed. In the last section (6-11) the differential up-regulation of $\mathrm{H}$-subunit rich ferritins during the acute phase response, the importance of $\mathrm{H}$-subunit rich ferritins in the withholding of iron by the macrophage, as well as its role in immune modulation, its pro-apoptotic and anti-apoptotic activities, and variations in cancer are addressed.

\section{The ferritin molecule: Sequestration, storage and release of iron}

The major functions of intracellular ferritin are the sequestration, storage and release of cellular iron. Body iron can be present as either the highly toxic $\mathrm{Fe}^{2+}$-ions or as harmless, insoluble $\mathrm{Fe}^{3+}$-ions. Ferritin detoxifies $\mathrm{Fe}^{2+}$-ions by converting them to the insoluble $\mathrm{Fe}^{3+}-$ 
ions. Ferritin can accumulate up to 4500 iron atoms as a ferrihydrite mineral in a hollow protein shell and releases these iron atoms when there is an increase in the cell's need for bio-available iron. The ferritin molecule consists of an outer three-dimensional protein shell with a diameter of 12-13 nm enclosing an inner cavity with a diameter of 7-8 $\mathrm{nm}$. In this inner cavity, ferritin is capable of sequestering variable amounts of $\mathrm{Fe}^{3+}$-atoms as a ferrihydrite mineral. The ferritin protein shell consists of 24 protein subunits of two types, the H-subunit and the L-subunit. These ferritin subunits perform different functions in the multi-step mineralization process of iron. $\mathrm{Fe}^{2+-}$-ions enter the ferritin cavity through channels in the protein shell facilitated by the presence of local iron binding sites. Upon entering the shell the $\mathrm{Fe}^{2+}$-ions are oxidized followed by hydrolysis, nucleation and iron core growth. Oxidation of the $\mathrm{Fe}^{2+}$-ions is an obligatory first step and is governed by the H-subunit's ferroxidase center which enzymatically oxidizes $\mathrm{Fe}^{2+}$-ions to $\mathrm{Fe}^{3+}$-ions. The subsequent hydrolysis and nucleation of the generated $\mathrm{Fe}^{3+}$-compound is brought about by the Lsubunit. The highly mobile $\mathrm{Fe}^{3+}$-monomers are directed to the inner cavity and properly placed on the protein shell/mineral interface by the L-subunit resulting in the formation of a ferrihydrite mineral core (Figure 1) (Chasteen, 1998; Harrison \& Arosio, 1996).

Two mechanisms are proposed for the release of iron from ferritin. Iron can be either released from the intact ferritin molecule or released upon the degradation of the ferritin molecule (Aisen, 1991; Deiss, 1983). Two processes are chemically feasible for removing iron from the intact ferritin molecule. The first process involves the reduction of $\mathrm{Fe}^{3+}$-ions to $\mathrm{Fe}^{2+}-$ ions followed by chelation of $\mathrm{Fe}^{2+}$-ions, and the second process the direct chelation of $\mathrm{Fe}^{3+-}$ ions (Gálvez et al., 2005; Harrison \& Arosio, 1996; Liu et al., 2003). The release of iron from ferritin by these processes is aided by reductants and iron chelators. Reductants and chelators gain access to the interior of the ferritin molecule through three-fold channels in the protein shell. It is suggested that the channels of the ferritin protein shell are dynamic and control the access of reductants and chelators, since reductants and chelators too large to pass through the channels can under certain conditions gain access to the interior of the ferritin molecule (Liu et al., 2003). Chaotropes can increase the access of reductants and chelators to the interior of ferritin by influencing the gating of the channel (Gálvez et al., 2005; Liu et al., 2003). Various reductants and chelators, including physiological and toxicological substances, can release iron from ferritin (Agrawal et al., 2001; Gálvez et al., 2005; Hynes \& Coinceanainn, 2002; Sánchez et al., 2005). The hydrous ferric oxide cores can be reduced by one electron per iron atom accompanied by an uptake of two protons per electron from the surrounding medium (Watt et al., 1985). This is then followed by the chelation of $\mathrm{Fe}^{2+}$-ions and the transport to sites where $\mathrm{Fe}^{2+}$-ions are needed (Joshi \& Clauberg, 1988; Watt et al., 1985). Effective reducing agents for the release of iron from ferritin include flavins, cysteine, glutathione, ascorbic acid and superoxide (Ponka et al., 1998). This mechanism for the release of iron from the intact ferritin molecule can provide the cell with iron for metabolic processes. However, the released iron may lead to the generation of free radicals that may damage the ferritin molecule itself (Rosseau \& Puntarulo, 2009).

In addition to the release of iron from the intact ferritin molecule iron can also be released upon the degradation of the ferritin molecule. Two mechanisms are known to be involved in the degradation of cytosolic ferritin, i.e., the $20 \mathrm{~S}$ proteasome enzymatic system in the cytosol, and proteolytic enzymes in the lysosomes. The proteolytic enzymes in the lysosomes appear to be of greater importance than the cytosolic proteasome enzymatic 
system for the degradation of ferritin and the subsequent release of iron (Kidane et al., 2006; Zhang et al., 2010). Specific iron chelators determine the route of ferritin degradation (De Domenico et al., 2009a). Depending on the type of cell, the iron status and whether ferritin is degraded free in the cytosol or within a lysosome, different amounts of iron are made available for metabolic processes. Degradation of ferritin in the cytosol results in the complete release of the iron from ferritin, whereas degradation of ferritin in the confinements of a lysosome can result in the entrapment of ferritin iron (Wixom et al., 1980). Cytosolic degradation may therefore be the major iron turnover mechanism providing the cell with easily accessible iron for shunting into metabolic pathways, while degradation within membrane-encapsulated secondary lysosomes, with subsequent haemosiderin formation, may prevent the uncontrolled release of iron and may become prominent when there is iron overload (Harrison \& Arosio, 1996; Wixom et al., 1980). Nevertheless, degradation of ferritin in lysosomes can also produce soluble iron, although these larger masses of ferritin/haemosiderin may require more time for the release of their iron contents. The iron so released would then be translocated back to the cytosol for reutilization in metabolic processes or for sequestration by ferritin (Deiss, 1983; Ponka et al., 1998; Radisky \& Kaplan, 1998). It seems as if the release of iron from lysosomes depends on the magnitude of aggregate formation and the subsequent deposition of iron as haemosiderin.

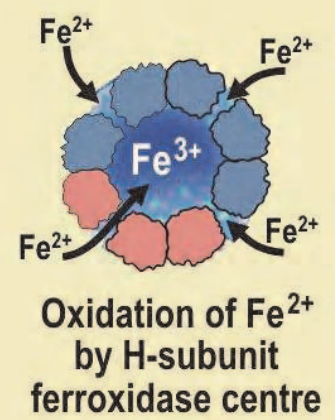

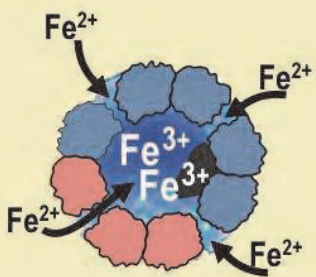

Nuclei formation and iron core growth

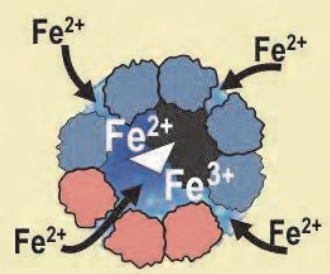

Oxidation of $\mathrm{Fe}^{2+}$ on the surface of the growing iron core

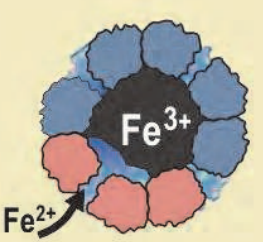

Iron core growth

Fig. 1. An animated presentation of ferritin molecules with eight subunits - five L-subunits in blue, and three H-subunits in red to show the mineralization process of iron by the ferritin protein shell. Oxidation of $\mathrm{Fe}^{2+}$ is performed by the ferroxidase centre of the $\mathrm{H}$ subunit. This is followed by nuclei formation and iron core growth facilitated by L-subunits. Once the iron core reaches a sufficient size oxidation of $\mathrm{Fe}^{2+}$ can take place on the surface of the iron core.

\section{The ferritin molecule: Isoferritins}

The multiple forms of ferritin have their molecular basis in the ratio of the two types of subunits, the H-subunit and the L-subunit. The ferritin protein shell can exist as heteropolymers of various combinations of these two types of subunits - a phenomenon that gives rise to the existence of isoferritins (Chiancone \& Stefanini, 1984). As the roles of the Hsubunit and L-subunit in the mineralization process differ, the subunit composition of 
ferritin will influence the metabolic properties of the assembled ferritin molecules (Harrison \& Arosio, 1996; Levi et al., 1994). H-subunit rich ferritins have been shown to accumulate and release iron faster than do L-subunit rich ferritins (Arosio et al., 1991; Chiancone \& Stefanini, 1984; Wagstaff et al., 1982; Worwood, 1990), and it is suggested that the H-subunit rich ferritins permit more dynamic intracellular traffic of iron (Chiancone \& Stefanini, 1984; Speyer \& Fielding, 1979). L-subunit rich ferritins apparently contain higher iron amounts than the H-subunit rich ferritins (Bomford et al., 1981; Chiancone \& Stefanini, 1984), and there are indications that the L-subunit rich ferritins predominate in cell types that play a role in iron storage (Boyd et al., 1985; Chiancone \& Stefanini, 1984; Coccia et al., 1992; Powell et al., 1975). It would further appear that a specific subunit composition may support iron storage, and that iron loading would increase the expression of the L-subunit upon which these L-subunit rich ferritins will sequester the bulk of the iron surplus (Bomford et al., 1981; Invernizzi et al., 1990). In general, L-subunit rich ferritins contain 1500 iron atoms or more, whereas H-subunit rich ferritins contain less than a 1000 iron atoms (Harrison \& Arosio, 1996). In situations of iron overload it may be advantageous to the cell to synthesize Lsubunit rich ferritins, since these ferritins are not only able to store higher iron amounts, but can also retain iron more firmly and turn over iron more slowly than their H-subunit rich counterparts (White \& Munro, 1988). The assumed role that the L-subunit rich ferritins play in the sequestration of the surplus iron during iron overload is underlined by the fact that their concentration in liver, serum and cultured cells is related to iron levels, whereas the Hsubunit rich ferritins appear either to be non-affected (in liver) or negatively affected (in serum) by increases in iron concentrations (Ruggeri et al., 1984). Furthermore, upon iron supplementation of patients with functional iron deficiency in the presence of tissue iron overload there would appear to be a proportionately greater change in L-subunit rich ferritins than in H-subunit rich ferritins (Ruggeri et al., 1984). Due to the H-subunit rich ferritin's more dynamic ability of iron uptake and release it would appear to be largely found in cells having high iron requirements for metabolic activities and a non-existent role in iron storage (Cazzola et al., 1983). Cells with a high content of H-subunit rich ferritins include erythroid cells, heart cells, pancreatic cells, kidney cells, lymphocytes and monocytes (Jones et al., 1983; Worwood, 1982), whereas the L-subunit rich ferritins are found predominantly in liver and spleen - organs associated with long-term iron storage (Powell et al., 1975; Worwood, 1982). The H- to L-subunit ratio of a specific type of cell does, however, not remain constant and the proportion of the $\mathrm{H}$ - and L-subunits present in the ferritin shell changes during differentiation and in various pathological states (Arosio et al., 1976; Boyd et al., 1985; Ponka et al., 1998; Theil, 1990).

\section{The ferritin molecule: iron-dependent regulation of the expression of the $\mathrm{H}$ - subunit and L-subunit}

Metabolically available iron is a major determinant of the regulation of ferritin expression. In order to accomplish a finely tuned system of ferritin expression as a function of the size of the metabolically available iron pool (the labile iron pool) the ferritin gene structure contains sequences that sense the size of the labile iron pool (Harford et al., 1994). The 5 '-untranslated region (5'-UTR) of both the H- and L-subunit mRNA contains a highly conserved 28-base sequence known as the iron-responsive element (IRE) sensitive to the metabolically active available iron (Worwood, 1990). The IREs are comprised of cis-acting nucleotide sequences. 
These nucleotide sequences form stem-loop structures that contain a six-membered loop with the sequence CAGUGN (Ponka et al., 1998). These stem-loop structures are recognized by trans-acting cytosolic RNA-binding proteins required for the coordinated expression of the H- and L-subunits (Theil, 1990). These cytosolic RNA-binding proteins, iron-responsive protein 1 (IRP1) and iron-responsive protein 2 (IRP2), cause a decrease in H- and L-subunit mRNA translation by binding to the stem-loop structures of the $5^{\prime}$-UTR of the respective mRNAs. IRP1 and IRP2 mediate the translational efficiency by obscuring the subsequent binding of the $43 \mathrm{~S}$ translation pre-initiation complex needed for the initiation of translation (Rogers et al., 1994). Although both the H-subunit and the L-subunit mRNA of ferritin contain an IRE, the IREs are regulated differentially. The IRE of the L-subunit mRNA was shown to be the primary responder to iron in hypoxic conditions, but this differential sensitivity is lost in normoxic conditions (Sammarco et al., 2008). IRP1 and IRP2 both sense and homeostatically control the metabolically available iron. For IRP1 this is accomplished by the existence of two conformationally distinct forms. IRP1 is a $90 \mathrm{kD}$ iron-sulphur cluster protein. When iron is abundant it exists as a cytosolic aconitase. When iron is scarce it assumes an open configuration associated with the loss of iron atoms from the iron-sulphur cluster and the subsequent binding to the IRE stem-loop structure, acting as a repressor of ferritin translation (Torti \& Torti, 2002). In contrast, the $105 \mathrm{kD}$ IRP2 protein is regulated by degradation: IRP2 protein is abundant in iron scarcity, but is degraded rapidly in iron excess through targeting of a unique 73 amino acid sequence and subsequent oxidation and ubiquitination (Meyron-Holtz et al., 1999; Torti \& Torti, 2002,). This response of ferritin synthesis to the size of the metabolically available pool of iron endows the cell with an exceptionally rapid mechanism for increasing ferritin synthesis upon iron influx. Iron influx increases the labile iron pool and, via binding to IRP1 and IRP2, causes a rapid increase in ferritin translation. This rapid response is achieved by a shift of stored mRNA from the ribonucleoprotein (RNP) fraction to polysomes (translational shift) (White \& Munro, 1988). The ferritin response to iron influx can thus be viewed as a protective rapid response system, allowing immediate formation of additional ferritin in which to store the surplus iron (Truty et al., 2001). Although the H-subunit and L-subunit mRNA shift from the RNP fraction to polysomes to the same extent (White \& Munro, 1988), the transcription of the Lsubunit gene is preferentially stimulated by an increase in metabolically available iron (Worwood, 1990) resulting in an increase in the ratio of L-subunit to H-subunit mRNA, which appears first in the RNP fraction and later in the polysomes (White \& Munro, 1988). This increase in the L-subunit to H-subunit mRNA ratio in the polysomes accounts for the change in the ratio of L-subunit to $\mathrm{H}$-subunit protein synthesis following iron administration (White \& Munro, 1988). Coordinated translational control and differential transcriptional control thus exist between these two genes (White \& Munro, 1988).

\section{Extracellular ferritin}

Most of the synthesized ferritin remains within the cell where it sequesters and releases iron in order to maintain intracellular iron homeostasis. Besides the presence of ferritin in the cytosol of the cell, ferritin is also found in smaller quantities in the plasma. It is suggested that ferritin may enter the circulation either via secretion of ferritin by cells or through the release of ferritin from damaged cells (Worwood, 1990). Both mechanisms probably contribute to plasma levels. Ferritin destined for intracellular iron homeostasis is 
synthesized on free polyribosomes, whereas a small amount of ferritin may be synthesized on the rough endoplasmic reticulum for secretion into the plasma (Covell \& Worwood, 1984; Cragg et al., 1981). The range of plasma ferritin in the normal adult varies between 15$300 \mu \mathrm{g} / 1$ (Covell \& Worwood, 1984; Worwood, 1990), and consists mainly of glycosylated Lsubunit rich ferritins containing insignificant amounts of iron, even in conditions of iron overload (Covell \& Worwood, 1984; Cragg et al., 1981; Jacobs \& Worwood, 1975; Ponka et al., 1998). For instance, while the iron content of ferritin in the liver and spleen could be more than $0.2 \mu \mathrm{g} \mathrm{Fe} / \mu \mathrm{g}$ protein in conditions of iron overload, the iron content of plasma ferritin may still be as low as $0.02-0.07 \mu \mathrm{g} \mathrm{Fe} / \mu \mathrm{g}$ protein (Worwood et al., 1976). Although the function of plasma ferritin is, as yet not completely clear, it is now known that extracellular ferritin can act as iron delivery system for ferritin receptor-mediated endocytosis by cells (Kalgaonkar \& Lonnerdal, 2009; Leimberg et al., 2008; Sibile et al., 1988). Extracellular ferritin has further been implicated in functions such as immune modulation, the regulation of myelopoiesis, as well as in the regulation of blood vessel formation, and modulation of bradykinin release and others (De Domenico et al., 2009b; Parthasara et al., 2002).

The concentration of ferritin in plasma is a function of the rate of secretion or release from cells and the clearance by other cells (Hershko \& Konijn, 1984). The major cell type responsible for the clearance of plasma ferritins is the hepatocyte. A specific receptor for both glycosylated and non-glycosylated ferritin has been demonstrated on the hepatocyte membrane (Hershko \& Konijn, 1984). These receptors bind both the H-subunit and the Lsubunit of ferritin (Halliday et al., 1979). However, a significant difference is indicated between the rates of clearance for the non-glycosylated ferritin of tissues, and the glycosylated plasma ferritin (Hershko \& Konijn, 1984). These differences in clearance may result in a significantly longer half-life for the glycosylated, secreted ferritins in the circulation compared to that of the non-glycosylated tissue ferritins (Bellotti et al., 1987; Halliday et al., 1979; Hershko \& Konijn, 1984; Worwood, 1990). The scavenger receptor (receptors that bind various ligands) SCARA5, has recently been identified as a cell surface receptor that preferentially binds to L-subunit rich ferritins followed by internalization ( $\mathrm{Li}$ et al., 2009). The clearance of ferritin may, however, also be influenced by the interaction between ferritin and other plasma components such as plasma proteins, ferritin-immune complexes and ferritin auto-antibodies. Of particular interest is the fact that $\alpha-2-$ macroglobulin has been identified as a ferritin binding protein (Massover, 1994). Alpha-2macroglobulin-binding is known to augment the clearance of substances from the circulation.

Under normal conditions a quantitative relationship exists between the level of plasma ferritin and the amount of storage iron (Cazzola \& Ascari, 1986). In conditions of iron overload there is generally an increase in the expression of intracellular L-subunit rich ferritins, paralleled by an increase in these ferritins in the plasma (Halliday \& Powell, 1979). Although the specific cellular origin of plasma ferritin is not known (Torti \& Torti, 1994), various experiments indicated a large contribution made by the reticulo-endothelial cells. An increase in plasma ferritin levels is known to occur in parallel with the increase in reticulo-endothelial cell ferritin after an increase in reticulo-endothelial cell iron during phagocytosis of non-viable red blood cells (Finch et al., 1984; Jacobs \& Worwood, 1975). However, elevated plasma ferritin levels are also seen in patients with parenchymal iron overload whose reticulo-endothelial cells are virtually devoid of iron (Finch et al., 1984).

Serum ferritin levels are determined in the clinic as part of iron studies and low ferritin levels in anaemic patients are generally considered indicative of iron deficiency anaemia 
(Guyatt et al., 1990). However, to use ferritin as a measure of body iron in the presence of inflammatory conditions woud lead to erroneous underestimation of the degree of iron deficiency. The reason for this is probably that although iron is a major trigger for the synthesis of ferritin, cytokines would appear to take over the central role in the regulation of ferritin synthesis during inflammatory conditions (Feelders et al., 1998). The cytokines involved in stimulation of ferritin synthesis are mainly of a pro-inflammatory nature and it is known that pro-inflammatory cytokine activity forms an integral part of the acute phase response. For the detection of iron deficiency in the presence of inflammation, several ways of correcting measured ferritin levels for the effect of inflammation have been suggested, amongst others by the World Health Organization (WHO, 2004 \& 2007). Inflammation may, however, be present at subclinical levels, yet influence the ferritin levels. In a meta-analysis, examining the adjustment of plasma ferritin concentrations to compensate for the effects of subclinical inflammation in the assessment of iron deficiency, Thurnham et al. (Thurnham et al., 2010) found the simultaneous measurement of C-reactive protein and $\alpha_{1}$-acidic glycoprotein to be a good estimate of the full effect of inflammation for the correction of ferritin levels.

Plasma ferritin concentration is affected by a number of factors other than the amount of storage iron and inflammatory activity. Other conditions known to influence plasma ferritin levels include tissue necrosis, damage to ferritin-rich tissue, infections, neoplastic disease, increased red blood cell turnover, malnutrition as in anorexia nervosa and surgery (Cazzola \& Ascari, 1986; Hershko \& Konijn, 1984; Kennedy et al., 2004; Rubin et al., 1984; Torti \& Torti, 1994; Worwood, 1982). When any of these conditions are present, the relationship between plasma ferritin concentration and amount of storage iron no longer holds. With tissue necrosis, as in hepatocellular injury, the increase in plasma ferritin is, for instance, due to the release of ferritin from the damaged cells, since the increase in ferritin is dependent on both the magnitude of cellular damage and liver iron stores (Halliday \& Powell, 1979). Furthermore, an increase in non-glycosylated, iron-rich ferritins has been reported upon tissue damage, which is indicative of the release of ferritin from damaged tissue, rather than an increase due to active secretion (Cragg et al., 1981).

Neoplastic diseases are in general accompanied by raised levels of ferritin in the plasma. It is suggested that the increase in plasma ferritin may be related to an increased production of ferritin by the malignant cells. In leukemia the normal concentration of ferritin in circulating leukocytes is increased up to six-fold in acute myeloblastic leukemia, more than twenty-fold in acute myelomonocytic leukemia, and two- to three-fold in chronic granulocytic leukemia (Jacobs \& Worwood, 1975). In the presence of various solid tumours, including tumours of the breast, pancreas and liver, an increase of $\mathrm{H}$-subunit rich ferritins was shown in the cells of the tumours, as well as an increase in plasma ferritin. In addition, the plasma ferritins reflected the increase in H-subunit rich ferritins of the tumours. Therefore the tumours seem to produce and secrete these H-subunit rich ferritins (Kew et al., 1978; Niitsu et al., 1984). This assumption, that the raised ferritin levels seen in a number of malignancies are the result of secretion from the malignant cells, does, however, not exclude the possibility of a further augmentation of plasma ferritin levels through cancer-related cytokine activity.

Raised levels of plasma ferritin have also been reported for Still's disease - a systemic inflammatory disorder (Evenson et al., 2007), the haemophagocytic syndrome - a disorder strongly associated with autoimmunity (Sekigawa et al., 2001), and in patients at risk for coronary artery disease and myocardial infarction (De Godoy et al., 2007). Low serum levels of ferritin were seen in neurological disorders such as neuroferritinopathy - a disorder of 
the basal ganglia, (Levi et al., 2005), in restless legs syndrome (Kotagal \& Silber, 2004), and in neurally-mediated syncopy in children and adolescents (Jarjour \& Jarjour, 2008). Plasma ferritin in these conditions would therefore not be a good indicator of iron stores.

Ferritin levels have, on occasion, been described as a biomarker for a number of pathologies (Goswami et al., 2009). Suggestions are that raised levels of ferritin can be used as biomarker for pathological conditions such as artherosclerosis, certain types of cancer, diabetes mellitus 2 , a number of pregnancy complications, foetal growth restriction and others (Goswami et al., 2009; Hou et al., 2000). Although increases in serum ferritin due to inherited disorders, such as haemochromatosis, porphyria, hereditary hyperferritinaemia-cataract syndrome (Kato \& Niitsu, 2002), and certain neurological diseases can occur, increases are generally not disease specific. The value of a raised ferritin level as differential diagnostic marker is therefore relatively limited as it is feasible to assume that the increased levels would predominantly be secondary to activities such as altered iron metabolism, oxidative stress, inflammatory processes and, in a small number of conditions, abnormal synthesis or clearance. Nevertheless, the determination of ferritin levels has been reported to have a role in the assessment of disease progression in conditions such as cancer, liver failure, acquired iron overload, multiple trauma, after organ transplantation, in acute and chronic inflammatory conditions and other (Wang et al., 2010). In addition to the identification of iron deficiency in otherwise normal individuals, and of iron overload, ferritin levels thus appear to be of clinical value in the assessment of prognosis and disease progression of certain disorders. Abnormal ferritin levels in the absence of abnormal total body iron may warrant further investigation. Although the value of ferritin as a reflection of body iron stores may be compromised during the acute phase response, the potential exists for ferritin as indicator of disease progression.

\section{Acute phase response, inflammatory response and ferritin}

The acute phase response is a systemic reaction to local or systemic infection, tissue damage, cancer and in general, immune disturbances. It is a non-specific, early defense system (Cray et al., 2009), and can therefore be seen as part of the innate immune system. The acute phase response is induced in the liver and also in various other tissues, and consists of both intracellular and extracellular acute phase proteins (Tilg et al., 1997). The inflammatory response, with the associated production of cytokines, forms an integral part of the acute phase response. Cytokines, both pro-inflammatory and anti-inflammatory, take part in the regulation of the production of the acute phase proteins, and mediate an increase in the socalled positive acute phase proteins and a decrease in the so-called negative acute phase proteins. Cytokines shown to modulate the production of acute phase proteins include the pro-inflammatory cytokines interleukin-1 $\beta$ (Il-1 $\beta$ ) and interleukin-6 (Il-6), (Ramadori \& Christ, 1999), and the anti-inflammatory cytokine interleukin-10 (Il-10) (El Kasmi et al., 2006). Up or down transcriptional regulation provides the necessary control for the synthesis of the acute phase proteins. One of the transcription factors involved in the synthesis of the acute phase proteins, signal transducer and activator of transcription 3 (stat3), originally named acute phase response factor (APRF), regulates the response to both pro- and anti-inflammatory cytokines (Desiderio \& Yoo, 2003; Turkson \& Jove, 2000). Ferritin is considered a positive acute phase protein and is up-regulated intracellularly in many cell types, and extracellularly, in the plasma as a result of an increase in cellular secretion. An important role for ferritin during the acute phase response is to restrict the 
availability of iron by sequestration into the cavity of the ferritin protein shell. Furthermore, ferritin can modulate many immune functions, play a role in pro-apoptotic and antiapoptotic pathways, and is implicated in the pathology of cancer.

Oxygen radicals, i.e., molecules containing unpaired electrons are generated in large amounts during infectious and inflammatory conditions (Di Virgilio, 2004). They react with proteins, lipids and nucleic acids, resulting in degradation of the phagocytosed material in the confinements of the phagosome in the neutrophil and macrophage. However, large amounts of these toxic metabolites leak to the fluids and tissues in the area of the inflammatory reaction and by reacting with cellular constituents can result in substantial damage (Closa \& Folch-Puy, 2004; Liu \& Pope, 2004). Iron, due to its role in Fenton-type chemistry, can result in exacerbation of oxygen radical production. Such an increase in unwanted oxygen radical production due to toxic amounts of iron can be seen in chronic inflammatory conditions. An increase in the iron content in the synovium is, for instance, present in rheumatoid arthritis (Giordano et al., 1991), and a significant correlation exists between thiobarbituric acid-reactive material (lipid peroxidation product), the amount of iron in the synovial fluid, and the inflammatory activity of the disease (Rowley et al., 1984). Furthermore, when anaemic rheumatoid arthritis patients receive iron supplementation, lipid peroxidation is stimulated resulting in worsening of the synovial inflammation (Blake et al., 1985).

In general, a reduction in the bio-availability of iron will offer protection against cell injury by hydroxyl radicals that are generated from neutrophil- and macrophage-derived superoxides (Rogers et al., 1990). Iron sequestration by cells in the zone of inflammation may therefore provide protection against the free radical assault (Rogers et al., 1994). This role of host cell protection against an increase in the free radical onslaught is consistent with observations that a reduction in ferritin sensitizes cells to pro-oxidant cytotoxicity, and that overexpression of ferritin reduces reactive oxidant species (ROS) in cells challenged by oxidants and by implication reduces the oxidative toxicity (Torti \& Torti, 1994). Macrophages, although contributing to the production of ROS, can also provide protection against it by reducing the available iron.

The restriction of bio-available iron during infections and inflammation controls the production of reactive oxygen species. In addition, with-holding of bio-available iron from micro-organisms can restrict their proliferation and spreading during infections. Most micro-organisms need a substantial amount of iron to ensure their survival and are endowed with various mechanisms and molecules to obtain iron from host ferroproteins such as haemoglobin, ferritin and transferrin (Ganz, 2009). For infections, such as tuberculosis, increased macrophage iron is associated with more severe infections with worse outcomes (Boelaert et al., 2007). Whereas, supplementing with iron can result in susceptibilty to malaria infections in areas with endemic malaria (Prentice, 2008). In order to suppress the growth of the pathogen the host responds by sequestering iron as evidenced by increased ferritin expression in the chronic phase of trypanosomiasis (Stijlemans et al., 2008).

\section{Differential up-regulation of $\mathrm{H}$-subunit rich ferritins during the acute phase response}

The overexpression of either the $\mathrm{H}$ - or the L- subunit is known to protect against oxidative stress (Orino et al., 2001). Nevertheless, the H-subunit rich ferritins have been shown to offer better protection than L-subunit rich ferritins. L-subunit rich ferritins predominate in cell types that play a role in the storage of iron (Boyd et al., 1985; Chiancone \& Stefanini, 1984; 
Powell et al., 1975), and there are indications that L-subunit rich ferritins contain more iron than those ferritins rich in H-subunits (Bomford et al., 1981; Chiancone \& Stefanini, 1984). However, rapid sequestration of iron is called for in inflammation to protect cells against the unwanted accumulation of reactive oxygen species that could damage various cellular components. H-subunit rich ferritins have been shown to accumulate and release iron faster than L-subunit rich ferritins (Arosio et al., 1991; Chiancone \& Stefanini, 1984; Wagstaff et al., 1982; Worwood, 1990), and it is suggested that the H-subunit rich ferritins permit a more dynamic intracellular traffic of iron than L-subunit rich ferritins (Chiancone \& Stefanini, 1984; Speyer \& Fielding, 1979). It is generally assumed that H-subunit rich ferritins are also responsible for the rapid sequestration of iron in situations where iron can contribute to damage to the cell (Arosio \& Levi, 2002), and that an increase in the expression of the Hsubunit rich ferritins protects the cell against oxidative stress by attenuating the production of hydroxyl radicals by the Fenton reaction (Cozzi et al., 2000; Zhao et al., 2006). The induction of H-subunit rich ferritins in vivo results in a phenotype of tissue-specific iron depletion. H-subunit rich ferritins can act as a potent regulator of iron metabolism in tissues and these effects can dominate normal iron homeostatic mechanisms (Wilkinson et al., 2006). However, cells can limit the accumulation of $\mathrm{H}$-subunits by differentially secreting $\mathrm{H}$ subunits in variance with L-subunits. Such a mechanism could play a significant role in regulating the amount of cytosolic $\mathrm{H}$-subunit rich ferritin and might protect the cell against unwarranted rapid sequestration of iron by H-subunit rich ferritins (Goralska et al., 2003).

Cytokines, central mediators of the inflammatory activity of the acute phase response, have been shown to up-regulate the expression of ferritin (Konijn \& Hershko, 1977; Piñero et al., 2000). Pro-inflammatory cytokines reported to have the ability to induce ferritin expression include Il-1 $\alpha$, Il-1 $\beta$, Il-2, Il-6, tumour necrosis factor- $\alpha$ (TNF- $\alpha$ ), and interferon- $\gamma$ (IFN- $\gamma$ ) (Miller et al., 1991; Pang et al., 1996; Rogers et al., 1990; Rogers, 1996; Stites et al., 1999; Torti \& Torti, 2002). These cytokines modulate ferritin expression by both transcriptional and translational mechanisms (Piñero et al., 2000), but largely by an increase in the rate of transcription of the ferritin genes (Miller et al., 1991; Torti \& Torti, 2002). Furthermore, cytokines differentially regulate the expression of the ferritin subunits, and it is mostly the $\mathrm{H}$-subunit of ferritin that is increased by cytokine induction at variance with the L-subunit (Miller et al., 1991; Pang et al., 1996; Rogers, 1996; Stites et al., 1999; Torti \& Torti, 2002).

Cytokines can also up-regulate the expression of ferritin by stimulating the production of reactive oxygen species. Pro-inflammatory cytokines increase the production of reactive oxygen species in various ways (Gougerot-Pocidalo et al., 2002; Yang et al., 2007). Furthermore, free oxygen radicals can, in turn, mediate signal transduction pathways that induce cytokine production and anti-oxidants have been shown to inhibit this transcriptional increase in the production of inflammatory cytokines (Ali et al., 1999; Blackwell et al., 1996; Dröge, 2002; Kosmidou et al., 2002; Tapia et al., 2003). An increase in oxidative stress is known to result in the transcriptional up-regulation of ferritin. This is part of a cellular anti-oxidant response induced by pro-oxidants to provide protection against reactive oxygen species. Induction of transcription is governed by the anti-oxidant responsive element (ARE) present in the ferritin genes upstream to the transcription initiation site. The H-subunit and the L-subunit genes both contain AREs, but at different positions upstream from the transcription initiation site and more importantly these AREs are regulated differentially (Hintze \& Theil, 2005; Iwasaki \& MacKenzie, 2006; Torti \& Torti, 1994). Damage to mitochondria with the consequent increase in iron-mediated reactive oxygen radical accumulation resulted in the preferential transcription of the H-subunit of ferritin governed by the ARE of the H-subunit's gene (MacKenzie et al., 2008). In addition, 
oxidants can also up-regulate the expresion of ferritin through their influence on IRP1 (Cairo et al., 1996; Orino et al., 2001; Tsuji et al., 2000), and by releasing iron from cellular proteins (Cairo et al., 1995).

\section{The macrophage, iron metabolism and $\mathrm{H}$-subunit rich ferritins during the acute phase response}

The macrophage is central to the decrease in plasma iron that is associated with immune activation. This hypoferraemic state is predominantly orchestrated by cytokines. Various iron homeostatic processes are affected by these cytokines with the combined actions resulting in entrapment of iron in the macrophage and a decrease in serum iron. This process is known as the iron transfer block (Weiss \& Goodnough, 2005). The so-called iron transfer block is generally associated with chronic inflammatory conditions. Inflammation, mediated by cytokines, produces a shift in iron handling by the macrophage in favour of iron storage, in time leading to hypoferraemia (Alvarez-Hernández et al., 1989; Fahmy \& Young, 1993; Worwood, 1990), haemosiderosis of the macrophage (Finch et al., 1984; Lipschitz et al., 1971; Worwood, 1990), and the anaemia of chronic disease (Weiss \& Goodnough, 2005). The latter is, however, only partly due to a decrease in iron available for haemotopoiesis as factors such as suppression of the proliferation of erythroid progenitor cells, a decrease in the synthesis of erythropoietin, a decrease in the sensitivity of erythroblasts to erythropoietin and a decrease in the red blood cell life span, contribute (Weiss \& Goodnough, 2005). Ferritin plays a major part in the establishment and maintenance of an iron transfer block and thus in the hypoferraemic state of the inflammatory reaction. TNF- $\alpha$, Il- $1 \beta$, Il- 6 and Il-10 have all been shown to directly stimulate the transcription and translation of ferritin (Ludwiczek et al., 2003; Weiss \& Goodnough, 2005). Activation of macrophages by cytokines such as, TNF- $\alpha$ and Il-1, results in the slower release of iron compared to non-stimulated macrophages, thus supporting the proposed role of cytokines in ferritin-mediated iron sequestration by macrophages (Alvarez-Hernández et al., 1986; Savarino et al., 1999). However, other iron homeostasis proteins also contribute to the reduction in serum iron. Most proteins involved in the acquisition, storage and release of iron are influenced, to different extents and at different time-points during the inflammatory reaction, by cytokines. With an inflammatory reaction the cytokine Il-6 has, for instance, been shown to stimulate the hepatic expression of the acute phase protein hepcidin. Hepcidin, in turn, inhibits duodenal absorption of iron by down-regulating ferroportin expression thus reducing serum iron (Ganz, 2004). IFN- $\gamma$, by increasing the expression of the divalent metal transporter 1 , has been shown to stimulate the uptake of ferrous iron by macrophages. Not only pro-inflammatory, but also anti-inflammatory cytokines are involved in the establishment of an iron transfer block. It has, for instance, been shown that Il-4 and Il-10 can up-regulate transferrin receptor expression, resulting in an increase in transferrin receptor-mediated uptake of iron by the macrophage (Ludwiczek et al., 2003; Weiss \& Goodnough, 2005). Furthermore, an increase in the phagocytosis and degradation of senescent erythrocytes is known to occur with an inflammatory reaction. This process is directly up-regulated by TNF- $\alpha$ stimulation as a result of the increase in the expression of C3bi (CD11b/CD18) receptors responsible for the recognition and uptake of damaged erythrocytes. In addition, $\mathrm{TNF}-\alpha$ can indirectly up-regulate this process by damaging circulating erythrocytes. These damaged erythrocytes are then phagocytosed upon binding to C3bi (CD11b/CD18) receptors followed by degradation (Ludwiczek et al., 2003; Weiss \& 
Goodnough, 2005). Not only is haemoglobin iron obtained by degradation of red blood cells, but free plasma haemoglobin is taken up by the haemoglobin scavenger receptor, CD163. Il10 and Il- 6 contribute to macrophage haemoglobin acquisition by stimulating the expression of the haemoglobin scavenger receptor, CD163 (Ludwiczek et al., 2003). INF- $\gamma$, downregulates the expression of ferroportin, the major transmembrane protein responsible for the release of macrophage iron, thus inhibiting iron export from macrophages (Ludwiczek et al., 2003), a process that is also affected by hepcidin (Deicher \& Hörl, 2006). Down-regulation of ferroportin occurs only later in the inflammatory response after the onset of hypoferraemia. It is therefore suggested that the down-regulation of ferroportin is not responsible for the development of the iron transfer block, but that it plays a major role in the maintenance of the iron transfer block (Ludwiczek et al., 2003). Many of the pro-inflammatory mediated effects on iron homeostasis are counterbalanced by anti-inflammatory cytokines such as IL-4 and IL-13 (Ludwiczek et al., 2003).

The abnormal retention of iron by the macrophage, due to an increase of ferritin synthesis, has long been seen as a non-specific acute phase reactant of inflammation (Konijn \& Hershko, 1977; Worwood, 1990). The increase in ferritin synthesis occurs prior to the reduction of serum iron levels and is considered to result in a diversion of iron from the intracellular labile iron pool to ferritin, and subsequently to haemosiderin (AlvarezHernández et al., 1986; Fillet et al., 1989; Jurado, 1997; Torrance et al., 1978; Worwood, 1990). The increase in ferritin expression by the macrophage mostly influences the early phase of iron release. In normal conditions two-thirds of the iron entering the macrophage/reticuloendothelial system (RES) is released during this phase, but an increase in ferritin expression can result in a decrease in the release of iron during this phase to only $10 \%$ of the iron entering the macrophage/RES (Fillet et al., 1974; Torrance et al., 1978). However, the slow release phase of iron from the macrophage is also influenced and can result in a situation where $33 \%$ of the iron is still present in storage form in the macrophage/RES after 60 days (Noyes et al., 1960). Furthermore, once the macrophage and other macrophage-like cells have been activated, as occurs during inflammation, these cells express increased levels of transferrin receptors (Fahmy \& Young, 1993), and are therefore able to acquire increased amounts of iron by endocytosis of the iron-transferrin-transferrin receptor complex. The increase in iron uptake via this route will contribute to the high magnitude of iron sequestration and to the ensuing haemosiderosis of macrophages and other macrophagelike cells. These iron-withholding mechanisms are implemented as a defense strategy in order to deplete biologically active iron in the zone of inflammation or, once the inflammatory response cannot be contained, systemically (Fuchs et al., 1993).

Haemosiderin formation can also aid in protection against iron toxicity. Haemosiderin is derived from ferritin as a result of degradation of the ferritin protein shell in secondary lysosomes (Finch et al., 1984; Fischbach et al., 1971; Ford et al., 1984). Evidence for this is found in observations that haemosiderin contains various amounts of degraded ferritin, as well as aggregated dense particles of irregular shape with diameters ranging from 10-75 $\AA$, which ultrastructurally resemble iron cores (Ringeling et al., 1989, Wixom et al., 1980), and that haemosiderin granules are recognised by anti-ferritin antibodies (Harrison \& Arosio, 1996). Ferritin is frequently found in secondary lysosomes and autophagosomes of normal cells, such as hepatocytes and macrophages, but its quantity in these organelles increases greatly after loading with iron (Richter, 1978) - demonstrating the protective function of haemosiderin formation against the toxicity of iron. Ferritin finds its way into lysosomes by 
autophagocytosis and/or fusion of ferritin clusters with the lysosomal membrane. Autophagocytosis is responsible for the turnover of cellular constituents including cellular proteins and involves the formation of autophagic vacuoles by invagination of intracytoplasmic membranes enclosing a relatively large volume of cytoplasm, together with various cellular constituents (Wixom et al., 1980). The autophagic vacuole receives digestive enzymes by fusion with a primary or secondary lysosome and becomes an autophagosome (Wixom et al., 1980). Within this lysosomal organelle the ferritin protein shell is degraded by the action of lysosomal proteases (Richter, 1984). It is suggested that the polymerization of ferritin (formation of oligomers of ferritin), which results in a change in solubility, heat stability and surface charge, may predispose ferritin to incorporation into lysosomes and transformation into haemosiderin (Chiancone \& Stefanini, 1984; Ringeling et al., 1989). Only once the ferritin protein shell has been modified, most probably by denaturation, resulting in the formation of insoluble ferritin molecules, does proteolytic decomposition of the ferritin protein shell by lysosomal enzymes take place (Richter, 1984). However, not all ferritin molecules in these lysosomal organelles are susceptible to the action of lysosomal proteases. Degradation of the ferritin protein shell results in the exposure of the iron oxyhydroxide mineral cores followed by aggregation of these oxyhydroxide particles and the formation of insoluble masses of iron oxyhydroxide (haemosiderin) (Fischbach et al., 1971; Richter, 1978; Weir et al., 1985). Although the main purpose of the formation of haemosiderin would appear to be protection against iron overload, these larger masses of ferritin/haemosiderin can, at a much slower rate, also release iron. This iron is then translocated back to the cytosol for reutilization in metabolic processes or for sequestration by ferritin (Deiss, 1983; Ponka et al., 1998; Radisky \& Kaplan, 1998). Haemosiderin is, however, not necessarily the end product as massive quantities of iron oxyhydroxide (haemosiderin) from these secondary lysosomes, can accumulate to form cytoplasmic organelles known as siderosomes (Richter, 1978). The haemosiderin-containing siderosomes can thus be regarded as the end-product of secondary lysosome action in which the wall of the original secondary lysosome now encapsulates the digested ferritin iron cores (Harrison \& Arosio, 1996; Wixom et al., 1980) - although clusters of electron-dense material without membranes or only partially enclosed membranes can also occur (Deiss, 1983; Harrison \& Arosio, 1996; Iancu, 1982). Within siderosomes, ferritin can be identified as individual particles, in clusters, in paracrystalline hexagonal arrays, or in circular arrangements (Iancu, 1992). In cells with marked iron overload, solitary siderosomes seem to fuse and to form larger bodies described as "compound siderosomes" (Iancu, 1992).

The formation of haemosiderin in reticulo-endothelial cells and other macrophage-like cells is influenced by inflammatory and infectious conditions. Macrophages subjected to increased oxidative stress also degrade ferritin faster than macrophages not challenged with an increase in the production of reactive oxygen species (Mehlhase et al., 2005). It is therefore, suggested that during inflammatory and infectious conditions the proportion of poorly accessible (non-chelatable) iron associated with ferritin similarly increases, suggesting a pathway from non-ferritin iron to loosely associated ferritin iron to a wellsequestered non-chelatable form existing as haemosiderin (Fahmy \& Young, 1993). Cytokines such as TNF- $\alpha$ and IFN- $\gamma$ may be responsible for these effects during inflammatory and infectious conditions. These cytokines may increase lysosomal activity resulting in increased degradation of intracellular ferritin, leading to the formation of haemosiderin, from which iron would be less easily liberated for subsequent extracellular release (Alvarez-Hernández et al., 1989). In vitro incubation of cells with either TNF- $\alpha$ or 
IFN- $\gamma$ increases the expression of ferritin H-subunit mRNA, but not L-subunit mRNA (Fahmy \& Young, 1993). Such a differential regulation of ferritin subunit expression might result in increased amounts of haemosiderin formation, since $\mathrm{H}$-subunit rich ferritins are more susceptible to lysosomal degradation.

$\mathrm{H}$-subunit rich ferritins have indeed been shown to play a role in the iron redistribution during inflammation, and also in the iron redistribution of the acute phase response. It has, as mentioned before, been reported that $\mathrm{H}$-subunit rich ferritins turnover more rapidly than L-subunit rich ferritins (Boyd et al., 1985; Truty et al., 2001; Worwood, 1982). Haemosiderin, which contains the degraded ferritin molecules as a result of the lysosomal breakdown of ferritin, shows the predominance of denatured subunits to be of the H-subunit type (Miyazaki et al., 2002; Ruggeri et al., 1992). A mechanism may therefore exist for preferentially directing ferritins rich in the H-subunit into lysosomes which would result in the formation of haemosiderin containing a high proportion of denatured H-subunits. It is already known that a too great proportion of $\mathrm{H}$-subunits in the ferritin protein shell results in ferritin aggregation (Harrison \& Arosio, 1996). This may be due to the inadequacy of the ferritin protein shell to retain the formed $\mathrm{Fe}^{3+}$-ions resulting in the loss of $\mathrm{Fe}^{3+}$-ions and hydrolysis of $\mathrm{Fe}^{3+}$-ions on the outside of the ferritin molecule (Harrison \& Arosio, 1996), which may be the signal for ferritin to be incorporated into lysosomes. Once inside the lysosome the presence of a large number of $\mathrm{H}$-subunits in the ferritin protein shell increases the chances of degradation (Bomford et al., 1981), since H-subunit rich ferritins, during denaturing conditions, are less stable than L-subunit rich ferritins (Kim et al., 2001; Miyazaki et al., 2002). The salt-bridge present in the L-subunit appears to be important for the differences in stabilities between H-subunit rich ferritins and L-subunit rich ferritins (Arosio et al., 1991). Futhermore, H-subunit rich ferritins are more susceptible to proteolysis due to less ordered secondary structures (Bomford et al., 1981). In particular the loop L becomes more exposed and/or less immobilized when the proportion of $\mathrm{H}$-subunits increases and therefore more accessible to lysosomal enzymes (Chiancone \& Stefanini, 1984).

\section{Immune modulation by secreted $\mathrm{H}$-subunit rich ferritins}

Many functions attributed to H-subunit rich ferritins point to a role for these isoferritins in immune modulation, including pro-inflammatory and anti-inflammatory activities. Hsubunit rich ferritins are present in most biologic fluids, but not, or only in low concentrations, in plasma (Morikawa et al., 1995). The ferritin present in plasma is mostly Lsubunit rich. However, during certain disease states the concentration of H-subunit rich ferritin is increased. At present it would appear that the $\mathrm{H}$-subunit rich ferritins are derived mostly from monocytes and macrophages as indicated by the secretion of $\mathrm{H}$-subunit rich ferritins from many monocyte-macrophage cell lines, as well as by monocytes from blood and bone marrow (Broxmeyer et al., 1984). In a recent study it was shown that murine serum ferritin is mainly secreted by macrophages through a non-classical secretion process involving secretory lysosomes and not the endoplasmic reticulum (Cohen et al., 2010). The release of H-subunit rich ferritins from monocytes appears to be controlled by T-cell subsets, where T-helper cells enhance the release and T-suppressor cells suppress the release (Worwood, 1990). These effects are most probably brought about by cytokines, since proinflammatory cytokines are known to induce the secretion of ferritin as part of the acute phase response. The secretion of ferritin was shown to be stimulated by cytokines in a primary human hepatocyte culture where IL-1 $\alpha$ and Il- 6 induced a transient secretion of 
ferritin at 24 hours, followed by a decline to baseline, while TNF- $\alpha$ treatment resulted in a sustained increase in ferritin secretion (Torti \& Torti, 2002).

$\mathrm{H}$-subunit rich ferritins can suppress various functions of immune cells. H-subunit rich ferritins can, for instance, exert inhibitory effects on E-rosette formation of T- lymphocytes (CD2 is the surface molecule on T-lymphocytes which facilitates binding to sheep erythrocytes and the formation of so-called E-rosettes), suppress the in vitro responses of lymphocytes to various mitogens including PHA and con A, inhibit the mixed-lymphocyte reaction, inhibit delayed-type hypersensitivity responses, block the access to T-lymphocytes by various regulatory factors by occupying the surface of the cells (Hie-won et al., 1984; Worwood, 1990), and decrease leukocyte migration (Worwood, 1990).

Receptors for $\mathrm{H}$-subunit rich ferritins have been found on various T-cell lines, CD4 and CD8 T-lymphocytes and on CD19 B-lymphocytes, and the expression of H-subunit rich ferritin binding sites on these cells appears to be closely and positively linked to their activation and proliferation status (Meyron-Holtz et al., 1994; Morikawa et al., 1995). It would therefore appear that H-subunit rich ferritins may perhaps act as feedback inhibitors of activation of peripheral blood cells. Quiescent circulating lymphocytes, reticulocytes, erythrocytes, and monocytes show little expression of the $\mathrm{H}$-subunit rich ferritin receptor, but PHAstimulated lymphocytes, erythropoietin-induced burst forming unit (BFU) cells, and differentiated macrophages have all been shown to express above average levels of the receptor (Halliday et al., 1994), which may result in these cells being more susceptible to inhibition by $\mathrm{H}$-subunit rich ferritins. Increased binding of $\mathrm{H}$-subunit rich ferritins to peripheral lymphocytes have also been shown to occur in patients with malignant disorders and the magnitude of $\mathrm{H}$-subunit rich ferritin binding to lymphocytes was shown to be related to the stage of the malignant process (Ciriello et al., 1987). It is postulated that two receptor systems exist for the binding and execution of H-subunit rich ferritin's effects. The first receptor system internalizes the bound ferritin. This system is similar to the receptor system operating in erythroid precursors. Developing erythroid cells in the bone marrow are often found in close proximity to a central "mother" reticulo-endothelial cell which supplies ferritin to these developing red blood cell precursors (Deiss, 1983; Jacobs et al., 1984). This process, known as rhopheocytosis, is a highly regulated pathway for iron assimilation by erythroid progenitor cells (Gelvan et al., 1996; Konijn et al., 1994; MeyronHoltz et al., 1994). However, a regulatory effect on cell proliferation and maturation occurs, whereas in erythroid precursors such a regulatory effect has not been observed (MeyronHoltz et al., 1994; Meyron-Holtz et al., 1999). The second receptor system, with a Kd three orders of magnitude lower, does not result in the internalization of the bound ferritin (Meyron-Holtz et al., 1994; Meyron-Holtz et al., 1999). This suggests a mechanism for the regulation of cellular proliferation and maturation by ferritin not involving iron or the sequestration of iron.

Three specific receptors involving binding and internalization of $\mathrm{H}$-subunit rich ferritins have been identified recently. The first involves a receptor identical to TIM-2 (member of the T-cell immunoglobulin and mucin-domain gene family) that specifically binds extracellular $\mathrm{H}$-subunit rich ferritins followed by the internalization of $\mathrm{H}$-subunit rich ferritins, and is expressed in B-cells and in non-haematopoietic organs such as the liver and kidney. Internalization of the H-subunit rich ferritins resulted in immunosuppression by inhibiting T-cell activation (Knickelbein et al., 2006). The second receptor that binds H-subunit rich ferritins is transferrin receptor 1 . The binding of $\mathrm{H}$-subunit rich ferritins to this receptor resulted in entry into endosomes and lysosomes (Li et al., 2010). The third receptor involves 
the CXCL12 chemokines and their receprtors. It has been shown that $\mathrm{H}$-subunit rich ferritins can repress chemokine receptor-mediated signal transduction and migration of lymphocytes by binding to the CXCL12 chemokine's receptor (Li et al., 2006). The CXCL12 chemokines have chemotactic and various activating effects that play important roles in T-helper cell responses. H-subunit rich ferritins have been found to bind to the CXCL12's cell surface receptors (CXCR4) in the presence of CXCL12. This complex, consisting of CXCL12 and the $\mathrm{H}$-subunit rich ferritin together with the receptor, are then internalized by the cell. On the inside of the cell the H-subunit rich ferritins are phosphorylated followed by nuclear translocation. Furthermore, intracellular H-subunit rich ferritins can repress CXCR4 activation followed by inhibition of lymphocyte migration (Li et al., 2006).

Most of the immunomodulatory studies involving H-subunit rich ferritins seem to be of an anti-inflammatory nature. However, it was recently shown that $\mathrm{H}$-subunit rich ferritins could also activate a pro-inflammatory pathway by an iron-independent mechanism (Ruddell et al., 2009). Ruddell et al. observed that hepatic stellate cells, treated with ferritin, set in motion a pathway involving phosphatidylinositol 3-kinase (PI3-kinase) phosphorylation, protein kinase $\mathrm{C}$ zeta and mitogen-activated protein kinase (MAP-kinase) activation, resulting in $\mathrm{NFKB}$ activation and eventually in increased pro-inflammatory activity. Activation of this pro-inflammatory pathway results in the enhanced production of various pro-inflammatory mediators including Il-1 $\beta$, inducible nitric oxide synthase (iNOS), the chemokine - regulated on activation normal T-cell expressed and secreted (RANTES), inhibitor of $\kappa \mathrm{B} \alpha$ and intercellular adhesion molecule 1 (iCAM1) (Ruddell et al., 2009). Based on these findings ferritin has been proposed as a pro-inflammatory signal molecule.

A number of other immune-related effects have been attributed to these $\mathrm{H}$-subunit rich plasma ferritins, including the down-regulation of myelopoiesis and regulation of angiogenesis (Broxmeyer et al., 1984; De Domenico et al., 2009b). It has specifically been shown that H-subunit rich ferritins, but not L-subunit rich ferritins, down-regulate myelopoiesis (Broxmeyer et al., 1986), i.e., the growth and development of granulocytes, macrophages, erythrocytes, and platelets (Broxmeyer, 1992; Joshi \& Clauberg, 1988), both in vitro and in vivo. It has been suggested that $\mathrm{H}$-subunit rich ferritins constitute part of a normal inhibitory feedback mechanism for the proliferation of granulocyte-macrophage colony forming units (CFU-GM), multipotential colony forming units (CFU-GEMM), and erythroid burst forming units (BFU-E) (Broxmeyer, 1992; Jacobs et al., 1984). H-subunit rich ferritin decreases the proliferation of cells during myelopoiesis by directly affecting these progenitor cells (Broxmeyer, 1992). Surface receptors specific for H-subunit rich ferritins have been shown on these progenitor cells (Fargion et al., 1988). These effects of H-subunit rich ferritins are mediated via the ferroxidase activity of the H-subunits - most probably by inducing intracellular iron starvation (Cozzi et al., 2000; Morikawa et al., 1995), since addition of iron completely counteracts the inhibitory effects of the H-subunit rich ferritins (Broxmeyer et al., 1991).

\section{Pro-apoptotic and anti-apoptotic activity of $\mathrm{H}$-subunit rich ferritins during inflammation}

During inflammation the proliferation and apoptosis of specific immune cells determine the course of the inflammatory response. H-subunit rich ferritins play a role in both proapoptotic and anti-apoptotic pathways, not only due to its ability to donate or sequester 
iron, but also by mechanisms not involving iron. During inflammation, an increase in reactive oxygen species (ROS) generation by cytokines is shown to be one of the mechanisms whereby cytokines induce apoptosis in cells. Tumour necrosis factor- $\alpha$ (TNF$\alpha)$, a pro-inflammatory cytokine, is known to induce apoptosis in many cell types during inflammation (Sharma \& Anker, 2002). The mechanism by which TNF- $\alpha$ brings about an accumulation of ROS and apoptosis involves up-regulation of the labile iron pool (Pham et al., 2004). This ROS formation induced by TNF- $\alpha$ is mediated by c-Jun N-terminal kinase 1dependent (JNK1) ferritin degradation and subsequent elevation in the labile iron pool (Antosiewicz et al., 2007). As H-subunit rich ferritins take-up iron faster and release iron faster than L-subunit rich ferritins it can donate or sequester iron resulting in an increase or decrease in ROS generation. In cells devoid of $\mathrm{H}$-subunit rich ferritins (reduction of intracellular iron storage caused by less $\mathrm{H}$-subunit rich ferritins) TNF- $\alpha$ can not bring about an increase in the labile iron pool, the accumulation of ROS and apoptosis. However, when TNF- $\alpha$ activation is accompanied by an increase in the expression of H-subunit rich ferritins, apoptosis is prevented by the sequestration of iron and the subsequent decrease in ROS production (Xie et al., 2005). Thus $\mathrm{H}$-subunit rich ferritins can antagonize this cytokineinduced apoptosis by sequestration of iron, preventing reactive oxygen species accumulation (Vardhan et al, 2010). It has been found that H-subunit rich ferritin expression is induced by NF- $\kappa B$ transcription factors. H-subunit rich ferritins prevent sustained c-Jun $\mathrm{N}$-terminal kinase cascade activation by TNF- $\alpha$ by reducing the production of ROS achieved through iron sequestration (Pham et al., 2004). Not only can H-subunit rich ferritins prevent apoptosis by the sequestration of iron, but $\mathrm{H}$-subunit rich ferritins can also cause apoptosis by the donation of iron. H-subunit rich ferritins secreted from hepatocytes induce apoptosis by the donation of iron to the target cell. H-subunit rich ferritins are released from the hepatocyte followed by endocytosis into the target cell. The internalized H-subunit rich ferritins increase the level of intracellular iron and support the production of ROS (Bresgen et al., 2010). Endocytosis of extracellular H-subunit rich ferritins increases the level of iron, promotes Fenton chemistry-based oxidative stress, induces damage to DNA, results in p53 activation, increases mitochondrial membrane permeability and activates pro-apoptotic Fas signalling (Bresgen et al., 2010).

$\mathrm{H}$-subunit rich ferritins have also been found to take part in the apoptotic events not involving iron or its ferroxidase activity. Upon oxidative stress, H-subuint rich ferritins increase p53 protein levels and p53 transcriptional activity in a ferroxidase activityindependent manner (Lee et al., 2009). The gene coding for the H-subunit of ferritin belongs to the family of p53-regulated genes. Therefore, p53 activation can bring about an increase in $\mathrm{H}$-subunit rich ferritins to support p53 in its apoptotic role (Faniello et al., 2008).

\section{H-subunit rich ferritins and cancer}

High plasma ferritin levels have been reported for various types of cancers, irrespective of the amount of total body iron (Aulbert \& Scmidt, 1985). It has even been suggested that plasma ferritin levels can be used as tumour markers for prognostic purposes and for monitoring the activity of certain types of cancer (Aulbert \& Steffens, 1990; Silber et al., 1991). In patients with solid tumours, such as pancreatic carcinoma, lung cancer and hepatoma, there is a particularly high incidence of elevated plasma ferritin, and in patients 
with breast cancer, with metastasis, ferritin plasma concentrations are commonly elevated (Worwood, 1982). It is of interest that ferritin levels in breast cancer are not only raised in the plasma, but also in breast tissue (Ionescu et al., 2006; Weinstein et al., 1982). Squamous cell carcinoma of the head and neck is marked by increased plasma ferritin concentrations, which remains high in patients with a poor prognosis in contrast to patients with a favourable prognosis (Maxim \& Veltri, 1986). The plasma ferritin concentrations of patients with haematologic malignancies are well documented. Extremely high plasma ferritin levels were seen in acute myeloblastic leukemia whereas in complete remission ferritin plasma concentrations returned back to normal (Aulbert \& Schmidt, 1985). In Hodgkin's disease, plasma ferritin concentrations are said to be related to the stage of the disease, increasing from stage 1 to stage 4 (Worwood, 1982). In non-Hodgkin's lymphoma a remarkable correlation was found between plasma ferritin concentrations and tumour histology. The highest plasma ferritin concentrations are said to be found in patients with active histiocytic lymphoma and the lowest plasma ferritin concentrations in patients with lymphocytic lymphoma whereas intermediate plasma ferritin concentrations are found in patients with mixed histology (Worwood, 1982).

Many factors are suggested to contribute to the hyperferritinaemia associated with cancer, including inflammation, hepatic necrosis due to metastasis and chemotherapy, blood transfusions and a decrease in hepatic clearance of ferritin (Vernet et al., 1995). In addition, a modified and increased synthesis and secretion of ferritin by tumour cells occur (Aulbert \& Steffens, 1990; Kirkali et al., 1999; Vernet et al., 1995; Yang et al., 2001). In many instances the increased ferritin is shown to be H-subunit rich (Bevilacqua et al., 1988; Higgy et al., 1997; Jones et al., 1980; Tripathi \& Chatterjee, 1996; Vernet et al., 1995; Whittaker et al., 1984), and it has been suggested that the measurement of $\mathrm{H}$-subunit rich ferritin may be of value in the diagnosis of malignancy (Jones et al., 1980). In a study involving breast cancer patients it has been shown that H-subunit mRNA was directly related to axillary lymph node status, the presence of metastatic disease and to the clinical stage (Yang et al., 2001).

The secretion of $\mathrm{H}$-subunit rich ferritins in patients with cancer could be involved in the immunosupression seen in these patients. In in vitro studies, melanoma cells have, for instance, been found to release $\mathrm{H}$-subunit rich ferritins. These $\mathrm{H}$-subunit rich ferritins were able to suppress the response of peripheral blood lymphocytes stimulated by anti-CD3. These effects were mediated by the activation of regulatory T-cells to produce Il-10 (Gray et al., 2003). Similar indications were seen in patients with melanoma. H-subunit rich, but not L-subunit rich ferritins, were found to be elevated in melanoma patients, with the H-subunit to L-subunit ratio correlating with the levels of regulatory T-cells (Gray et al., 2003).

The most common feature of cancer is the abnormal proliferation of cells, either contained in a specific location, or following metastasis at different sites involving various organs. Iron is a necessary element for cellular proliferation and it is generally accepted that rapidly dividing cells require more iron for their growth and metabolism than resting cells, and that cells normally display an increase in cellular proliferation upon an increase in the labile iron pool (Kakhlon et al., 2001). Malignant cells, because of their higher requirement for iron, are very sensitive to iron depletion (Kalinowski et al., 2007). In addition, the cellular labile iron pool can modulate the magnitude of cellular proliferation by the oncogene H-ras (Kakhlon et al., 2002). It is already known that iron homeostasis is dysregulated in cancerous cells. For instance, human breast cancer cells are characterised by substantial alterations in the levels 
of proteins that are responsible for the maintenance of intracellular iron homeostasis, including transferrin, IRP1, IRP2, H-subunit and L-subunit of ferritin (Shpyleva et al., 2011). In view of their high need for iron, malignant cells would have mechanisms able to increase the labile iron pool. One way in which to bring about an increase in the cellular labile iron pool would be by suppression of ferritin synthesis. The transcription factor encoded by the proto-oncogene c-MYC, which is responsible for proliferation of normal cells, can during uncontrolled expression result in cellular transformation and excessive cellular proliferation. c-MYC can, where appropriate, activate or repress target genes in order to bring about cellular proliferation (Wu et al., 1999). The expression of the H-subunit gene is shown to be down-regulated by c-MYC and to be essential for the control of cellular proliferation and transformation by c-MYC (Wu et al., 1999). This is in agreement with the fact that H-subunit rich ferritins are responsible for controlling the labile iron pool and that down-regulation of $\mathrm{H}$-subunit expression would result in an increase in the labile iron pool. The downregulation of intracellular $\mathrm{H}$-subunit rich ferritins has also been shown to be required for the pathogenesis of cancer. Epithelial-mesenchymal transition (EMT) contributes to tumourinvasive phenotypes and metastasis. The down-regulation of $\mathrm{H}$-subunit rich ferritins was shown to occur between the early and highly invasive advanced stages in esophageal adenocarcinoma (Zhang et al., 2009). It is suggested that an increase in the labile iron pool plays a role, since depletion of the labile iron pool and a decrease in ROS suppress the migration of tumour cells (Zhang et al., 2009).

In contrast, up-regulation of intracellular H-subunit rich ferritins has been shown in several studies (Elliot et al., 1993; Shpeleva et al., 2011; Weinstein et al., 1982). In the study by Shpeleva et al., involving human breast cancer, an increase in the expression of the H-subunit and Lsubunit intracellular levels of ferritin was associated with a decrease in the labile iron pool (Shpeleva et al., 2011). This increase in the production of intracellular ferritin, together with an increase in the H-subunit rich ferritin in the chromatin-bound nuclear fraction, is postulated to be one of the defense mechanisms in cancer cells against iron-induced toxicity. Furthermore, the increase in intracellular ferritin production has been associated with the acquisition of a metastatic and multi-drug resistant phenotype (Shpeleva et al., 2011). It was also shown that down-regulation of the H-subunit of ferritin increased the cancer cell's sensitivity to the chemotherapeutic agent Doxorubicin (Shpeleva et al., 2011).

At present, many research studies support the concept that an increase in intracellular bioavailable iron can augment the development and progression of cancer. Although low intracellular ferritin concentrations, and by implication high intracellular iron levels, could favour the proliferation of malignant cells, plasma ferritin levels are generally high in patients with cancer. As plasma ferritin is generally a secretory product of cells it is unlikely that intracellular ferritin levels would be low in conjunction with excessively high extracellular levels. In fact, measurements of tissue ferritin levels showed, in general, increased levels of ferritin in malignant breast tissues, at least in advanced more aggressive stages (Elliot et al., 1993; Shpeleva et al., 2011; Weinstein et al., 1982). As a rule, one would expect these high intracellular ferritin levels to decrease bio-available iron - which is contrary to the requirement of cancer cells. The answer to this conundrum is largely still at the conjectural stage. Research is necessary to distinguish between observations that reflect attempts of malignant cells to create conditions favourable for proliferation and those of the body to protect against such proliferation. What we do know is that iron metabolism is dysregulated in cancer, and that changes occur in both intracellular and extracellular ferritin 
pools. Although some work exists on the redistribution of ferritin and iron, the type of ferritin, as well as the cancer phenotype and stage of malignancy (Cade et al., 1998; Kabat \& Rohan, 2007; Rossiello et al., 1984; Shpeleva et al., 2011; Wu et al., 2004), more studies are urgently needed.

\section{Conclusion}

Up-regulation of ferritin during the acute phase response protects against microbial growth, oxidative damage, and is involved in the regulation of immunological activity, apoptotic processes and cellular proliferation. During most of these activities the $\mathrm{H}$-subunit of ferritin is differentially up-regulated, and appears to play a more important role than the L-subunit in establishing ferritin's functional properties during the acute phase response.

\section{Acknowledgement}

The authors would like to acknowledge the Publisher of "Archives of Physiology and Biochemistry" for permission to use adapted exerpts from the authors' own publications, Koorts, A.M. \& Viljoen, M. (2007). Ferritin and ferritin isoforms I: Structure-function relationships, synthesis, degradation and secretion. Arch Physiol Biochem, 113(1) (2007), pp. (30-54) and Koorts, A.M. \& Viljoen, M. (2007). Ferritin and ferritin isoforms II: Protection against uncontrolled cellular proliferation, oxidative damage and inflammatory processes. Arch Physiol Biochem, 113(2) (2007), pp. (55-64).

\section{References}

Agrawal, R.; Sharma, P.K. \& Rao, G.S. (2001). Release of iron from ferritin by metabolites of benzene and superoxide radical generating agents. Toxicol, 168 (2001), pp. (223-230).

Aisen, P. (1991). Ferritin receptors and the role of ferritin in iron transport. Targeted Diag Ther, 4 (1991), pp. (339-354).

Ali, M.H.; Schlidt, S.A.; Chandel, N.S.; Hynes, K.L.; Schumacker, P.T. \& Gewertz, B.L. (1999). Endothelial permeability and IL-6 production during hypoxia: role of ROS in signal transduction. Am J Physiol, 277(5) (1999), pp. (L1057-L1065).

Alvarez-Hernández, X.; Felstein, M.V. \& Brock, J.H. (1986). The relationship between iron release, ferritin synthesis and intracellular iron distribution in mouse peritoneal macrophages. Evidence for a reduced level of metabolically available iron in elicited macrophages. Biochim Biophys Acta, 886 (1986), pp. (214-222).

Alvarez-Hernández, X.; Licéaga, J.; McKay, I.C. \& Brock, J.H. (1989). Induction of hypoferremia and modulation of macrophage iron metabolism by tumor necrosis factor. Lab Invest, 61(3) (1989), pp. (319-322).

Antosiewicz, J.; Ziolkowski, W.; Kaczor, J.J. \& Herman-Antosiewicz, A. (2007). Tumor necrosis factor-alpha-induced reactive oxygen species formation is mediated by JNK1-dependent ferritin degradation and elevation of labile iron pool. Free Radic Biol Med, 43(2) (2007), pp. (265-270).

Arosio, P.; Yokota, M. \& Drysdale, J.W. (1976). Structural and immunological relationships of isoferritins in normal and malignant cells. Cancer Res, 36 (1976), pp. (1735-1739). 
Arosio, P.; Levi, S.; Santambrogio, P.; Cozzi, A.; Luzzago, A.; Cesareni, G. \& Albertini, A. (1991). Structural and functional studies of human ferritin H and L chains. Curr Stud Hematol Blood Transf, 58 (1991), pp. (127-131).

Arosio, P. \& Levi, S. (2002). Ferritin, iron homeostasis, and oxidative damage. Free Radic Biol Med, 33(4) (2002), pp. (457-463).

Aulbert, E. \& Schmidt, C.G. (1985). Ferritin - a tumor marker in myeloid leukaemia. Cancer Detect Prev, 8(1-2) (1985), pp. (297-302).

Aulbert, E. \& Steffens, O. (1990). Serum ferritin - a tumor marker in malignant lymphomas? Onkologie, 13(2) (1990), pp. (102-108).

Bellotti, V.; Arosio, P.; Cazzola, M.; Cozzi, A.; Levi, S.; Meloni, F. \& Zoppone, E. (1987). Characteristics of a ferritin-binding protein present in human serum. Br J Haematol, 65(4) (1987), pp. (489-493).

Bevilacqua, M.A.; Costanzo, F.; Buonaguro, L. \& Cimino, F. (1988). Ferritin H and L mRNAs in human neoplastic tissues. Ital J Biochem, 37(1) (1988), pp. (1-7).

Blackwell, T.S.; Blackwell, T.R.; Holden, E.P.; Christman, B.W. \& Christman, J.W. (1996). In vivo antioxidant treatment suppresses nuclear factor-kappa B activation and neutrophilic lung inflammation. J Immunol, 157(40) (1996), pp. (1630-1637).

Blake, D.R.; Lunec, J.; Ahern, M.; Ring, E.F.; Bradfield, J. \& Gutteridge, J.M. (1985). Effect of intravenous iron dextran on rheumatoid synovitis. Ann Rheum Dis, 44(3) (1985), pp. (183-188).

Boelaert, J.R.; Vandecasteele, S.J.; Appelberg, R. \& Gordeuk, V.R. (2007). The effect of the host's iron status on tuberculosis. J Infect Dis, 195 (2007), pp. (1745-1753).

Bomford, A.; Conlon-Hollingshead, C. \& Munro, H.N. (1981). Adaptive responses of rat tissue isoferritins to iron administration. J Biol Chem, 256(2) (1981), pp. (948-955).

Boyd, D.; Vecoli, C.; Belcher, D.M.; Jain, S.K. \& Drysdale, J.W. (1985). Structural and functional relationships of human ferritin $\mathrm{H}$ and $\mathrm{L}$ chains deduced from cDNA clones. J Biol Chem, 260(21) (1985), pp. (11755-11761).

Bresgen, N.; Jaksch, H.; Lacher, H.; Ohlenschlager I.; Uchida, K. \& Eckl, P.M. (2010). Ironmediated oxidative stress plays an essential role in ferritin-induced cell death. Free Radic Biol Med, 48(10) (2010), pp. (1347-1357).

Broxmeyer, H.E.; Gentile, P.; Listowsky, I.; Cavanna, E.; Feickert, H.J.; Dorner, M.H.; Ruggeri, G.; Cazzola, M. \& Cooper, S. (1984). Acidic isoferritins in the regulation of hematopoiesis in vitro and in vivo, In: Ferritins and isoferritins as biochemical markers, Albertini, A.; Arosio, P.; Chiancone, E. \& Drysdale, J., pp. (97-111), Elsevier Science Publishers, Amsterdam.

Broxmeyer, H.E.; Lu, L.; Bicknell, D.C.; Williams, D.E.; Cooper, S.; Levi, S.; Salfeld, J. \& Arosio, P. (1986). The influence of purified recombinant human heavy-subunit and light-subunit ferritins on colony formation in vitro by granulocyte-macrophage and erythroid progenitor cells. Blood, 68(6) (1986), pp. (1257-1263).

Broxmeyer, H.E.; Cooper, S.; Levi, S. \& Arosio, P. (1991). Mutated recombinant human heavy-chain ferritins and myelosuppression in vitro and in vivo: a link between ferritin ferroxidase activity and biological function. Proc Natl Acad Sci USA, 88 (1991), pp. (770-774).

Broxmeyer, H.E. (1992). H-ferritin: a regulatory cytokine that down-modulates cell proliferation. J Lab Clin Med, 120(3) (1992), pp. (367-370). 
Cade, J.; Thomas, E. \& Vail, A. (1998). Case-control study of breast cancer in south east England: nutritional factors. Epidemiol Community Health, 52 (1998), pp. (105-110).

Cairo, G.; Tacchini, L.; Pogliaghi, G.; Anzon, E.; Tomasini, A. \& Bernelli-Zazzera, A. (1995). Induction of ferritin synthesis by oxidative stress: transcriptional and posttranscriptional regulation by expansion of the free iron pool. J Biol Chem, 270 (1995), pp. (700-703).

Cairo, G.; Castrosini, E.; Minotti, G. \& Bernelli-Zazzera, A. (1996). Superoxide and hydrogen peroxide-dependent inhibition of iron regulatory protein activity: a protective strategem against oxidative injury. FASEB J, 10 (1996), pp. (1326-1335).

Cazzola, M.; Dezza, L.; Bergamaschi, G.; Barosi, G.; Bellotti, V.; Caldera, D.; Ciriello, M.M.; Quaglini, S.; Arosio, P. \& Ascari, E. (1983). Biologic and clinical significance of red cell ferritin. Blood, 62(5) (1983), pp. (1078-1087).

Cazzola, M. \& Ascari, A. (1986). Red cell ferritin as a diagnostic tool. Br J Haematol, 62(2) (1986), pp. (209-213).

Chasteen, N.D. (1998). Ferritin. Uptake, storage, and release of iron. Met Ions Biol Syst, 35 (1998), pp. (479-514).

Chiancone, E. \& Stefanini, S. (1984). Heterogeneity of ferritin. I. Structural and functional aspects, In: Ferritins and isoferritins as biochemical markers, Albertini, A.; Arosio, P.; Chiancone, E. \& Drysdale, J, pp. (23-32), Elsevier Science Publishers, Amsterdam.

Ciriello, M.M.; Cazzola, M.; Dezza, L.; Levi, S. \& Arosio, P. (1987). Measurement of ferritinbearing lymphocytes in man. Preliminary studies on the use of monoclonal antibodies specific for the L and H subunits of ferritin. Tumori, 73 (1987), pp. (3741).

Closa, D. \& Folch-Puy, E. (2004). Oxygen free radicals and the systemic inflammatory response. IUBMB Life, 56(4) (2004), pp. (185-191).

Coccia, E.M.; Profita, V.; Fiorucci, G.; Romeo, G.; Affabris, E.; Testa, U.; Hentze, M.W. \& Battistini, A. (1992). Modulation of ferritin H-chain expression in Friend erythroleukemia cells: transcriptional and translational regulation by hemin. $\mathrm{Mol}$ Cell Biol, 12(7) (1992), pp. (3015-3022).

Cohen, L.A.; Gutierrez, L.; Weiss, A.; Leichtmann-Bardoogo, Y.; Zhang, D-L.; Crooks, D.R.; Sougrat, R.; Morgenstern, A.; Galy, B.; Hentze, M.W.; Lazaro, F.J.; Rouault, T.A. \& Meyron-Holtz, E.G. (2010). Serum ferritin is derived primarily from macrophages through a nonclassical secretory pathway. Blood, 116(9) (2010), pp. (1574-1584).

Covell, A.M. \& Worwood, M. (1984). Isoferritins in plasma, In: Ferritins and isoferritins as biochemical markers, Albertini, A.; Arosio, P.; Chiancone, E. \& Drysdale, J., pp. (4965), Elsevier Science Publishers, Amsterdam.

Cozzi, A.; Corsi, B.; Levi, S.; Santambrogio, P.; Albertini, A. \& Arosio, P. (2000). Overexpression of wild type and mutated human ferritin H-chain in HeLa cells: in vivo role of ferroxidase activity. J Biol Chem, 275(3) (2000), pp. (25122-25129).

Cragg, S.J.; Wagstaff, M. \& Worwood, M. (1981). Detection of a glycosylated subunit in human serum ferritin. Biochem J, 199 (1981), pp. (565-571).

Cray, C.; Zalas, J. \& Altman, N.H. (2009). Acute phase response in animals: a review. Comparative Med, 59(6) (2009), pp. (517-526).

De Domenico, I.; Ward, D.M. \& Kaplan, J. (2009a). Specific iron chelators determine the route of ferritin degradation. Blood, 114(20) (2009), pp. (4546-4551). 
De Domenico, I.; Ward, D.M. \& Kaplan, J. (2009b). Serum ferritin regulates blood vessel formation: a role beyond iron storage. PNAS, 106(6) (2009), pp. (1683-1684).

De Godoy, M.F.; Takakura, I.T.; Machado, R.D.; Grassi, L.V. \& Nogueira, P.R. (2007). Serum ferritin and obstructive coronary artery disease: angiographic correlation. Arq Bras Cardiol, 88(4) (2007), pp. (430-433).

Deicher, R. \& Hörl, W.H. (2006). New insights into the regulation of iron homeostasis. Eur J Clin Invest, 36 (2006), pp. (301-309).

Deiss, A. (1983). Iron metabolism in reticuloendothelial cells. Semin Hematol, 20(2) (1983), pp. (81-90).

Desiderio, S. \& Yoo, J.Y. (2003). A genome-wide analysis of the acute-phase response and its regulation by Stat3ß. Ann NY Acad Sci, 987 (2003), pp. (280-284).

Di Virgilio, F. (2004). New pathways for reactive oxygen species generation in inflammation and potential novel pharmacological targets. Curr Pharm Design, 10(14) (2004), pp. (1647-1652).

Dröge, W. (2002). Free radicals in the physiological control of cell function. Physiol Rev, 82(1) (2002), pp. (47-95).

El Kasmi, K.C.; Holst, J.; Coffre, M.; Mielke, L.; de Pauw, A.; Lhocine, N.; Smith, A.M.; Rutschman, R.; Kaushal, D.; Shen, Y.; Suda, T.; Donnelly, R.P.; Myers Jr., M.G.; Alexander, W.; Vignali, D.A.A.; Watowich, S.S.; Ernst, M.; Hilton, D.J. \& Murray, P.J. (2006). General nature of STAT3-activated anti-inflammatory response. J Immunol, 177(11) (2006), pp. (7880-7888).

Elliot, R.L.; Elliot, M.C.; Wang, F. \& Head J.F. (1993). Breast carcinoma and the role of iron metabolism. A cytochemical, tissue culture, and ultrastructural study. Ann $N Y$ Acad Sci, 698 (1993), pp. (159-166).

Evenson, K.J.; Swaak, T.J. \& Nossent, J.C. (2007). Increased ferritin response in adult Still's disease: specificity and relationship to outcome. Scand J Rheumatol, 36(2) (2007), pp. (107-110).

Fahmy, M. \& Young, S.P. (1993). Modulation of iron metabolism in monocyte cell line U937 by inflammatory cytokines: changes in transferrin uptake, iron handling and ferritin mRNA. Biochem J, 296 (1993), pp. (175-181).

Faniello, M.C.; Di Sanzo, M.; Quaresima, B.; Baudi, F.; Di Caro, V.; Cuda, G.; Morrone, G.; Del Sal, G.; Spinelli, G.; Venuta, S. \& Costanzo, F. (2008). p53-mediated downregulation of $\mathrm{H}$ ferritin promoter transcriptional efficiency via NF-Y. Int J Biochem Cell Biol, 40(10) (2008), pp. (2110-2119).

Fargion, S.; Arosio, P.; Fracanzani, A.L.; Cislaghi, V.; Levi, S.; Cozzi, A.; Piperno, A. \& Fiorelli, G. (1988). Characteristics and expression of binding sites specific for ferritin H-chain on human cell lines. Blood, 71 (1988), pp. (753-757).

Feelders, R.A.; Vreugdenhil, G.; Eggermont, A.M.; Kuiper-Kramer, P.A.; van Eijk, H.G. \& Swaak, A.J. (1998). Regulation of iron metabolism in the acute-phase response: interferon gamma and tumour necrosis factor alpha induce hypoferraemia, ferritin production and a decrease in circulating transferrin receptors in cancer patients. Eur J Clin Invest, 28(7) (1998), pp. (520-527).

Fillet, G.; Cook, J.D. \& Finch, C.A. (1974). Storage iron kinetics. VII. A biologic model for reticuloendothelial iron transport. J Clin Invest, 53 (1974), pp. (1527-1533). 
Fillet, G.; Beguin, Y. \& Baldelli, L. (1989). Model of reticuloendothelial iron metabolism in humans: abnormal behavior in idiopathic hemochromatosis and in inflammation. Blood, 74(2) (1989), pp. (844-851).

Finch, C.A.; Huebers, H.A.; Cazzola, M.; Bergamaschi, G. \& Bellotti, V. (1984). Storage iron, In: Ferritins and isoferritins as biochemical markers, Albertini, A.; Arosio, P.; Chiancone, E. \& Drysdale, J., pp. (3-21), Elsevier Science Publishers, Amsterdam.

Fischbach, F.A; Gregory, D.W.; Harrison, P.M.; Hoy, T.J. \& Williams, J.M. (1971). On the structure of hemosiderin and its relationship to ferritin. J Ultrastr Res, 37 (1971), pp. (495-503).

Ford, G.C.; Harrison, P.M.; Rice D.W.; Smith, J.M.; Treffry, A.; White, J.L. \& Yariv, J. (1984). Ferritin: design and formation of an iron-storage molecule. Phil Trans $R$ Soc Lond, 304 (1984), pp. (551-565).

Fuchs, D.; Zangerle, R.; Artner-Dworzak, E.; Weiss, G.; Fritsch, P.; Tilz, G.P.; Dierich, M.P. \& Wachter, H. (1993). Association between immune activation, changes of iron metabolism and anaemia in patients with HIV infection. Eur J Haematol, 50 (1993), pp. (90-94).

Gálvez, N.; Ruiz, B.; Cuesta, R.; Colacio, E. \& Dominguez-Vera, J.M. (2005). Release of iron from ferritin by aceto- and benzohydroxamic acids. Inorg Chem, 44(8) (2005), pp. (2706-2709).

Ganz, T. (2004). Hepcidin in iron metabolism. Curr Opin Hematol, 11 (2004), pp. (251-254).

Ganz, T. (2009). Iron in innate immunity: starve the invaders. Curr Opin Immunol, 21(1) (2009), pp. (63-67).

Gelvan, D.; Fibach, E.; Meyron-Holtz, E.G. \& Konijn, A.M. (1996). Ferritin uptake by human erythroid precursors is a regulated iron uptake pathway. Blood, 88(8) (1996), pp. (3200-3207).

Giordano, N.; Vaccai, D.; Cintorino, M.; Minacci, C.; Magaro, L.; Battisti, E.; Marcuccil, P.; Cecconami, L. \& Marcolongo, R. (1991). Histopathological study of iron deposit distribution in the rheumatoid synovium. Clin Exp Rheumatol, 9(5) (1991), pp. (463467).

Goralska, M.; Holley, B.L. \& McGahan, M.C. (2003). Identification of a mechanism by which lens epithelial cells limit accumulation of overexpressed ferritin H-chain. J Biol Chem, 278(44) (2003), pp. (42920-42926).

Goswami, B.; Tayal, D. \& Mallika, V. (2009). Ferritin: A multidimensional biomarker. Internet J Lab Med, 3(2) (2009).

Gougerot-Pocidalo, M.A.; El Benna, J.; Elbim, C.; Chollet-Martin, S. \& Dang, M.C. (2002). Regulation of human neutrophil oxidative burst by pro- and anti-inflammatory cytokines. J Soc Biol, 196(1) (2002), pp. (37-46).

Gray, C.P.; Arosio, P. \& Hersey, P. (2003). Association of increased levels of heavy-chain ferritin with increased $\mathrm{CD}^{+} \mathrm{CD} 25^{+}$regulatory $\mathrm{T}$-cell levels in patients with melanoma. Clin Cancer Res, 9 (2003), pp. (2551-2559).

Guyatt, G.; Patterson, C.; Ali, M.; Singer, J.; Levine, M.; Turpie, I. \& Meyer, R. (1990). Diagnosis of iron-deficiency anemia in the elderly. Am J Med, 88(3) (1990), pp. (205209).

Halliday, J.W.; Mack, U. \& Powell, L.W. (1979). The kinetics of serum and tissue ferritins: relation to carbohydrate content. Br J Haematol, 42 (1979), pp. (535-546). 
Halliday, J.W. \& Powell, L.W. (1979). Serum ferritin and isoferritins in clinical medicine. Progr Hematol, 11 (1979), pp. (229-266).

Halliday, J.W.; Ramm, G.A.; Moss, D. \& Powell, L.W. (1994). A new look at ferritin metabolism. Adv Exp Med Biol, 365 (1994), pp. (149-156).

Harford, J.B.; Rouault, T.A. \& Klausner, R.D. (1994). The control of cellular iron homeostasis, In: Iron metabolism in health and disease, Brock, J.H.; Halliday, J.W.; Pippard, M.J. \& Powell L.W., pp. (123-149), W.B. Saunders Company Ltd, London.

Harrison, P.M. \& Arosio, P. (1996). The ferritins: molecular properties, iron storage function and cellular regulation. Biochim Biophys Acta, 1275 (1996), pp. (161-203).

Hershko, C. \& Konijn, A.M. (1984). Serum ferritin in hematologic disorders, In: Ferritins and isoferritins as biochemical markers, Albertini, A.; Arosio, P.; Chiancone, E. \& Drysdale, J., pp. (143-158), Elsevier Science Publishers, Amsterdam.

Hie-won, L.; Stahlhut, M.W. \& Evans, A.E. (1984). Isoferritins and prognosis of neuroblastoma: the immunological role of acidic isoferritins, In: Ferritins and isoferritins as biochemical markers, Albertini, A.; Arosio, P.; Chiancone, E. \& Drysdale, J., pp. (171-180), Elsevier Science Publishers, Amsterdam.

Higgy, N.A.; Salicioni, A.M.; Russo, I.H.; Zhang, P.L. \& Russo, J. (1997). Differential expression of human ferritin $\mathrm{H}$ chain gene in immortal human breast epithelial MCF-10F cells. Mol Carcinogen, 20(4) (1997), pp. (332-339).

Hintze, K.J. \& Theil, E.C. (2005). DNA and mRNA elements with complementary responses to hemin, antioxidant inducers, and iron control ferritin-L expression. Proc Natl Acad Sci USA, 102 (2005), pp. (15048-15052).

Hou, J.; Cliver, S.P.; Tamura, T.; Johnston, K.E. \& Goldenberg, R. (2000). Maternal serum ferritin and fetal growth. Obstet Gynecol, 95(3) (2000), pp. (447-452).

Hynes, M.J. \& Coinceanainn, M.O. (2002). Investigation of the release of iron from ferritin by naturally occurring antioxidants. J Inorg Biochem, 90 (2002), pp. (18-21).

Iancu, T.C. (1982). Iron overload. Mol Aspects Med, 6 (1982), pp. (1-100).

Iancu, T.C. (1992). Ferritin and hemosiderin in pathological tissues. Electron Microsc Rev, 5 (1992), pp. (209-229).

Invernizzi, R.; Caccola, M.; De Fazio, P.; Rosti, V.; Ruggeri, G. \& Arosio, P. (1990). Immunocytochemical detection of ferritin in human bone marrow and peripheral blood cells using monoclonal antibodies specific for the $\mathrm{H}$ and $\mathrm{L}$ subunit. $\mathrm{Br} \mathrm{J}$ Haematol, 76 (1990), pp. (427-432).

Ionescu, J.G.; Novotny, J.; Stejskal, V.; Latsch, A.; Blaurock-Bush, E. \& Eisenmann-Klein, M. (2006). Increased levels of transition metals in breast cancer tissue. Neuro Endocrinol Lett, 27(Suppl1) (2006), pp. (36-39).

Iwasaki, K. \& Mackenzie, E.L. (2006). Hemin-mediated regulation of an anti-oxidantresponsive element of the human ferritin $\mathrm{H}$ gene and role of Ref- 1 during erythroid differentiation of K562 cells. Mol Cell Biol, 26 (2006), pp. (2845-2856).

Jacobs, A. \& Worwood, M. (1975). Ferritin in serum; clinical and biochemical implications. New Engl J Med, 292(18) (1975), pp. (951-956).

Jacobs, A.; Hodgetts, J. \& Hoy, T.G. (1984). Functional aspects of isoferritins, In: Ferritins and isoferritins as biochemical markers, Albertini, A.; Arosio, P.; Chiancone, E. \& Drysdale, J., pp. (113-127), Elsevier Science Publishers, Amsterdam.

Jarjour, I.T. \& Jarjour, L.K. (2008). Low iron storage in children and adolescents with neurally mediated syncopy. J Pediatr, 153 (2008), pp. (40-44). 
Jones, B.M.; Worwood, M. \& Jacobs, A. (1980). Serum ferritin in patients with cancer: determination with antibodies to HeLa cell and spleen ferritin. Clin Chim Acta, 106 (1980), pp. (203-214).

Jones, B.M.; Worwood, M. \& Jacobs, A. (1983). Isoferritins in normal leucocytes. Br J Haematol, 55(1) (1983), pp. (73-81).

Joshi, J.G. \& Clauberg, M. (1988). Ferritin: an iron storage protein with diverse functions. Biofactors, 1(3) (1997), pp. (207-212).

Jurado, R.L. (1997). Iron, infections, and anemia of inflammation. Clin Infect Dis, 25 (1997), pp. (888-895).

Kabat, C.C. \& Rohan, T.F. (2007). Does excess iron play a role in breast carcinogenesis? An unresolved hypothesis. Cancer Cause Control, 18 (2007), pp. (1047-1053).

Kakhlon, O.; Gruenbaum, Y. \& Cabantchik, Z.I. (2001). Repression of ferritin expression increase the labile iron pool, oxidative stress, and short-term growth of human erythroleukemia cells. Blood, 97(9) (2001), pp. (2853-2871).

Kakhlon, O.; Gruenbaum, Y. \& Cabantchik, Z.I. (2002). Repression of ferritin expression modulates cell responsiveness to H-ras-induced growth. Biochem Soc Trans, 30(4) (2002), pp. (777-780).

Kalgaonkar, S. \& Lonnerdal, B. (2009). Receptor-mediated uptake of ferritin-bound iron by human intestinal caco-2 cells. J Nutr Biochem, 20 (2009), pp. (304-311).

Kalinowski, D.S.; Sharpe, P.C.; Bernhardt, P.V. \& Richardson, D.R. (2007). Design, synthesis, and characterization of new iron chelators with anti-proliferative activity: structure-activity relationships of novel thiohydrazone analogues. J Med Chem, 50(24) (2007), pp. (6212-6225).

Kato, J. \& Niitsu, Y. (2002). Recent advances in molecular iron metabolism: translational disorders of ferritin. Int J Hematol, 76(3) (2002), pp. (208-212).

Kennedy, A.; Kohn, M.; Lammi, A. \& Clarke, S. (2004). Iron status and haematological changes in adolescent female inpatients with anorexia nervosa. J Paediatr Child Health, 40(8) (2004), pp. (430-432).

Kew, M.C.; Torrance, J.D.; Derman, D.; Simon, M.; Macnab, G.M.; Charlton, R.W. \& Bothwell, T.H. (1978). Serum and tumour ferritins in primary liver cancer. Gut, 19(4) (1978), pp. (294-299).

Kidane, T.Z.; Sauble, E. \& Linder, M.C. (2006). Release of iron from ferritin requires lysosomal activity. Am J Physiol Cell Physiol, 291(3) (2006), pp. (C445-C455).

Kim, S-W.; Kim, Y-H. \& Lee, J. (2001). Thermal stability of human ferritin: concentration dependence and enhanced stability of an N-terminal fusion mutant. Biochem Biophys Res Commun, 289 (2001), pp. (125-129).

Kirkali, Z.; Guzelsoy, M.; Mungan, M.U.; Kirkali, G. \& Yorokoglu, K. (1999). Serum ferritin as a clinical marker for renal cell carcinoma: influence of tumor size and volume. Urol Int, 62(1) (1999), pp. (21-25).

Knickelbein, J.E.; de Souza, A.J.; Tosti, R.; Narayan, P. \& Kane, L.P. (2006). Cutting edge: inhibition of T cell activation by TIM-2. J Immunol, 177 (2006), pp. (4966-4970).

Konijn, A.M. \& Hershko, C. (1977). Ferritin synthesis in inflammation. I. Pathogenesis of impaired iron release. Br J Haematol, 37(1) (1977), pp. (7-16).

Konijn, A.M.; Meyron-Holtz, E.G.; Fibach, E. \& Gelvan, D. (1994). Cellular ferritin uptake: a highly regulated pathway for iron assimilation in human erythroid precursor cells. Adv Exp Med Biol, 356 (1994), pp. (189-197). 
Kosmidou, I.; Vassilakopoulos, T.; Xagorari, A.; Zakynthinos, S; Papapetropoulos, A. \& Roussos, C. (2002). Production of interleukin-6 by skeletal myotubes: role of reactive oxygen species. Am J Resp Cell Mol Biol, 26(5) (2002), pp. (587-593).

Kotagal, S. \& Silber, M.H. (2004). Childhood-onset restless legs syndrome. Ann Neurol, 56(6) (2004), pp. (803-807).

Lee, J.H.; Jang, H.; Cho, E.J. \& Youn, H.D. (2009). Ferritin binds and activates p53 under oxidative stress. Biochem Biophys Res Commun, 389(3) (2009), pp. (399-404).

Leimberg, M.J.; Prus, E.; Konijn, A.M. \& Fibach, E. (2008). Macrophages function as a ferritin iron source for cultured human erythroid precursors. J Cell Biochem, 103(4) (2008), pp. (1211-1218).

Levi, S.; Santambrogio, P.; Cozzi, A.; Rovida, E.; Corsi, B.; Tamborini, E.; Spada S.; Albertini, A. \& Arosio P. (1994). The role of the L-chain in ferritin iron incorporation; studies of homo and heteropolymers. J Mol Biol, 238 (1994), pp. (649-654).

Levi, S.; Cozzi, A. \& Arosio, P. (2005). Neuroferritinopathy: a neurodegenerative disorder associated with L-ferritin mutation. Best Pract Res Clin Hamatol, 18(2) (2005), pp. (265-276).

Li, J.Y.; Paragas, N.; Ned, R.M.; Qiu, A.; Viltard, M.; Leete, T. Drexler, I.R.; Chen, X.; SannaCherchi, S.; Mohammed, F.; Williams, D.; Lin, C.S.; Schmidt-Ott, K.M.; Andrews, N.C. \& Barasch, J. (2009). Scara5 is a ferritin receptor mediating non-transferrin iron delivery. Dev Cell, 16(1) (2009), pp. (35-46).

Li, L.; Fang, C.J.; Ryan, J.C.; Niemi, E.C.; Lebron, J.A.; Bjorkman, P.J.; Arase, H.; Torti, F.M.; Torti, S.V.; Nakamura, M.C. \& Seaman, W.E. (2010). Binding and uptake of Hferritin are mediated by human transferrin receptor-1. Proc Natl Acad Sci USA, 107(8) (2010), pp. (3505-3510).

Li, R.; Luo, C.; Mines, M.; Zhang, J. \& Fan, G.H. (2006). Chemokine CXCL12 induces binding of ferritin heavy chain to the chemokine receptor CXCR4, alters CXCR4 signaling, and induces phosphorylation and nuclear translocation of ferritin heavy chain. $J$ Biol Chem, 281(49) (2006), pp. (37616-37627).

Lipschitz, D.A.; Simon, M.O.; Lynch, S.R.; Dugard, J.; Bothwell, T.H. \& Charlton, R.W. (1971). Some factors affecting the release of iron from reticuloendothelial cells. $\mathrm{Br} \mathrm{J}$ Haematol, 21 (1971), pp. (289-303).

Liu, H. \& Pope, R.M. (2004). Phagocytes: mechanisms of inflammation and tissue destruction. Rheum Dis Clin North Am, 30(1) (2004), pp. (19-39).

Liu, X.; Jin, W. \& Theil, E.C. (2003). Opening protein pores with chaotropes enhances Fe reduction and chelation of Fe from the ferritin biomineral. PNAS, 100(7) (2003), pp. (3653-3658).

Ludwiczek, S.; Aigner, E.; Theurl, I. \& Weiss, G. (2003). Cytokine-mediated regulation of iron transport in human monocytic cells. Blood, 101(10) (2003), pp. (4148-4154).

MacKenzie, E.L.; Ray, P.D. \& Tsuji, Y. (2008). Role and regulation of ferritin H in rotenonemediated mitochondrial oxidative stress. Free Radic Biol Med, 44(9) (2008), pp. (17621771).

Massover, W.H. (1994). Alpha-2-macroglobulin: a ferritin binding protein. Ann N Y Acad Sci, 737 (1994), pp. (468-471).

Maxim, P.E. \& Veltri, R.W. (1986). Serum ferritin as a tumor marker in patients with squamous cell carcinoma of the head and neck. Cancer, 57(2) (1986), pp. (305-311). 
Mehlhase, J.; Sandig, G.; Pantopoulos, K. \& Grune, T. (2005). Oxidation-induced ferritin turnover in microglial cells: role of proteasome. Free Radic Biol Med, 38 (2005), pp. (276-285).

Meyron-Holtz, E.G.; Fibach, E.; Gelvan, D. \& Konijn, A.M. (1994). Binding and uptake of exogenous isoferritins by cultured human erythroid precursor cells. Br J Haematol, 86 (1994), pp. (635-641).

Meyron-Holtz, E.G.; Vaisman, B.; Cabantchik, Z.I.; Fibach, E.; Rouault, T.A.; Hershko, C. \& Konijn, A.M. (1999). Regulation of intracellular iron metabolism in human erythroid precursors by internalized extracellular ferritin. Blood, 94(9) (1999), pp. (3205-3211).

Miller, L.L.; Miller, S.C.; Torti, S.V.; Tsuji, Y. \& Torti, F.M. (1991). Iron-independent induction of ferritin $\mathrm{H}$ chain by tumor necrosis factor. Proc Natl Acad Sci USA, 88(11) (1991), pp. (4946-4950).

Miyazaki, E.; Kato, J.; Kobune, M.; Okumura, K.; Sasaki, K.; Shintani, N.; Arosio, P. \& Niitsu, Y. (2002). Denatured H-ferritin subunit is a major constituent of haemosiderin in the liver of patients with iron overload. Gut, 50 (2002), pp. (413-419).

Morikawa, K.; Oseko, F. \& Morikawa, S. (1995). A role for ferritin in hematopoiesis and the immune system. Leuk Lymphoma, 18 (2005), pp. (429-433).

Niitsu, Y.; Onodera, Y.; Kohgo, Y.; Goto, Y.; Watanabe, N. \& Urushizaki, I. (1984). Isoferritins in malignant diseases, In: Ferritins and isoferritins as biochemical markers, Albertini, A.; Arosio, P.; Chiancone, E. \& Drysdale, J., pp. (113-127), Elsevier Science Publishers, Amsterdam.

Noyes, W.D.; Bothwell, T.H. \& Finch, C.A. (1960). The role of the reticulo-endothelial cell in iron metabolism. Br J Haematol, 6 (1960), pp. (43-55).

Orino, K.; Lehman, L.; Tsuji, Y.; Ayaki, H.; Torti, S.V. \& Torti, F.M. (2001). Ferrritin and the response to oxidative stress. Biochem J, 357 (2001), pp. (241-247).

Pang, J-H.S.; Jiang, M-J.; Chen, Y-L.; Wang, F-W.; Wang, D.L.; Chu, S-H. \& Chau, L-Y. (1996). Increased ferritin gene expression in atherosclerotic lesions. J Clin Invest, 97(10) (1996), pp. (2204-2212).

Parthasara, N.; Torti, S.V. \& Torti, F.M. (2002). Ferritin binds to light chain of human Hkininogen and inhibits kallikrein-mediated bradykinin release. Biochem J, 365 (2002), pp. (279-286).

Pham, C.G.; Bubici, C.; Zazzeroni, F.; Papa, S.; Jones, J.; Alvarez, K.; Jayawardena, S.; De Smaele, E.; Cong, R.; Beaumont, C.; Torti, F.M.; Torti, S.V. \& Franzoso, G. (2004).

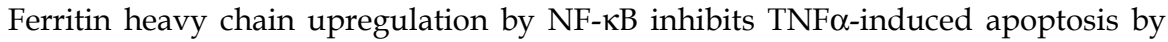
suppressing reactive oxygen species. Cell, 119 (2004), pp. (529-542).

Piñero, D.J.; Hu, J.; Cook, B.M.; Scaduto Jr., R.C. \& Connor, J.R. (2000). Interleukin-1 $\beta$ increases binding of the iron regulatory protein and the synthesis of ferritin by increasing the labile iron pool. Biochim Biophys Acta, 1497 (2000), pp. (279-288).

Ponka, P.; Beaumont, C. \& Richardson, D.R. (1998). Function and regulation of transferrin and ferritin. Semin Hematol, 35(1) (1998), pp. (35-54).

Powell, L.W.; Alpert, E.; Isselbacher, K.J. \& Drysdale, J.W. (1975). Human isoferritins: organ specific iron and apoferritin distribution. Br J Haematol, 30 (1975), pp. (47-132).

Prentice, A.M. (2008). Iron metabolism, malaria, and other infections. What is all the fuss about? J Nutr, 138 (2008), pp. (2537-2541). 
Radisky, D.C. \& Kaplan, J. (1998). Iron in cytosolic ferritin can be recycled through lysosomal degradation in human fibroblasts. Biochem J, 336 (1998), pp. (201-205).

Ramadori, G. \& Christ, B. (1999). Cytokines and the hepatic acute-phase response. Semin Liver Dis, 19(2) (1999), pp. (141-155).

Richter, G.W. (1978). The iron-loaded cell - the cytopathology of iron storage. Am J Pathol, 91(2) (1978), pp. (363-404).

Richter, G.W. (1984). Studies of iron overload; rat liver siderosome ferritin. Lab Invest, 50(1) (1984), pp. (26-35).

Ringeling, P.L.; Cleton, M.I.; Kroos, M.J.; Sorber, L.W.; de Bruyn, W.C.; Harrison, P.M. \& van Eijk, H.G. (1989). Lysosomal and cytosolic ferritins. A biochemical and electronspectroscopic study. Biol Metals, 2 (1989), pp. (114-121).

Rogers, J.T.; Bridges, K.R.; Durmowicz, G.P.; Glass, J.; Auron, P.E. \& Munro, H.N. (1990). Translational control during the acute phase response; ferritin synthesis in response to interleukin-1. J Biol Chem, 265(24) (1990), pp. (14572-14578).

Rogers, J.; Lacroix, L.; Durmowitz, G.; Kasschau, K.; Andriotakis, J. \& Bridges, K.R. (1994). The role of cytokines in the regulation of ferritin expression. Adv Exp Med Biol, 356 (1994), pp. (127-132).

Rogers, J.T. (1996). Ferritin translation by interleukin-1 and interleukin-6: the role of sequences upstream of the start codons of the heavy and light subunit genes. Blood, 87(6) (1996), pp. (2525-2537).

Rossiello, R.; Carriero, M.V. \& Giordano, G.G. (1984). Distribution of ferritin, transferrin and lactoferrin in breast carcinoma tissue. J Clin Pathol, 37 (1984), pp. (51-55).

Rousseau, I. \& Puntarulo, S. (2009). Ferritin-dependent radical generation in rat liver homogenates. Toxicol, 264(3) (2009), pp. (155-161).

Rowley, D.; Gutteridge, J.M.; Blake, D.; Farr, M. \& Halliwell, B. (1984). Lipid peroxidation in rheumatoid arthritis: thiobarbituric acid-reactive material and catalytic iron salts in synovial fluid from rheumatoid patients. Clin Sci, 66(6) (1984), pp. (691-695).

Rubin, C.; Wood, P.J.; Archer, T. \& Rowe, D.J. (1984). Changes in serum ferritin and other acute phase proteins following major surgery. Ann Clin Biochem, 21(Pt 4) (1984), pp. (290-294).

Ruddell, R.G.; Hoang-Le, D.; Barwood, J.M.; Rutherford, P.S.; Piva, T.J.; Watters, D.J.; Santambrogio, P.; Arosio, P. \& Ramm, G.A. (2009). Ferritin functions as a proinflammatory cytokine via iron-independent protein kinase $\mathrm{C}$ zeta/nuclear factor kappaB-regulated signaling in rat hepatic stellate cells. Hepatol, 49(3) (2009), pp. (887-900).

Ruggeri, G.; Iacobello, C.; Albertini, A.; Brocchi, E.; Levi, S.; Gabri, E. \& Arosio, P. (1984). Studies of human isoferritins in tissues and body fluids, In: Ferritins and isoferritins as biochemical markers, Albertini, A.; Arosio, P.; Chiancone, E. \& Drysdale, J., pp. (6778), Elsevier Science Publishers, Amsterdam.

Ruggeri, G.; Santambrogio, P.; Bonfiglio, F.; Levi, S.; Bugari, G.; Verardi, R.; Cazzola, M.; Invernizzi, R.; Zambelli, L.M.; Albertini, A. \& Arosio, P. (1992). Antibodies for denatured human $\mathrm{H}$-ferritin stain only reticuloendothelial cells within the bone marrow. Br J Haematol, 81 (1992), pp. (118-124).

Sammarco, M.C.; Ditch, S.; Banerjee, A. \& Grabczyk, E. (2008). Ferritin H and L subunits are differentially regulated on a post-transcriptional level. J Biol Chem, 283(8) (2008), pp. (4578-4587). 
Sánchez, P.; Gálvez, N.; Colacio, E.; Miñones, E. \& Domínguez-Vera, J.M. (2005). Catechol releases iron(III) from ferritin by direct chelation without iron(II) production. Dalton Trans, (2005), pp. (811-813).

Savarino, A.; Pescarmona, G.P. \& Boelaert, J.R. (1999). Iron metabolism and HIV infection: reciprocal interactions with potentially harmful consequences. Cell Biochem Funct, 17 (1999), pp. (279-287).

Sekigwa, I.; Suzuki, J.; Nawata, M.; Ikeda, K.; Koike, M.; Lida, N.; Hashimoto, H. \& Oshimi, K. (2001). Hemophagocytosis in autoimmune disease. Clin Exp Rheumatol, 19(3) (2001), pp. (333-338).

Sharma, R. \& Anker, S.D. (2002). Cytokines, apoptosis and cachexia: the potential for TNF antagonism. Int J Cardiol, 85 (2002), pp. (161-171).

Shpyleva, S.I.; Tryndyak, V.P.; Kovalchuk, O.; Starlard-Davenport, A.; Chekhun, V.F.; Beland, F.A. \& Pogribny, I.P. (2011). Role of ferritin alterations in human breast cancer cells. Breast Cancer Res Treat, 126 (2011), pp. (63-71).

Sibile, J.C.; Kondo, H. \& Aisen, P. (1988). Interaction between isolated hepatocytes and Kupffer cells in iron metabolism: a possible role for ferritin as an iron carrier protein. Hepatol, 8 (1988), pp. (296-301).

Silber, J.H.; Evans, A.E. \& Fridman, M. (1991). Models to predict outcome from childhood neuroblastoma: the role of serum ferritin and tumor histology. Cancer Res, 51(5) (1991), pp. (1426-1433).

Speyer, B.E. \& Fielding, J. (1979). Ferritin as a cytosol iron transport intermediate in human reticulocytes. Br J Haematol, 42 (1979), pp. (255-267).

Stijlemans, B.; Vankrunkelsven, A.; Brys, L.; Magez, S. \& De Baetselier, P. (2008). Role of iron homeostasis in trypanosomiasis-associated anemia. Immunobiol, 213(9-10) (2008), pp. (823-835).

Stites, S.W.; Plautz, M.W.; Bailey, K.; O’Brien-Ladner, A.R. \& Wesselius, L.J. (1999). Increased concentrations of iron and isoferritins in the lower respiratory tract of patients with stable cystic fibrosis. Am J Resp Crit Care Med, 160(3) (1999), pp. (796801).

Tapia, G.; Fernández, V.; Varela, P.; Cornejo, P.; Guerrero, J. \& Videla, L.A. (2003). Thyroid hormone-induced oxidative stress triggers nuclear factor- $\kappa \mathrm{B}$ activation and cytokine gene expression in rat liver. Free Radic Biol Med, 35(3) (2003), pp. (257-265).

Theil, E.C. (1990). The ferritin family of iron storage proteins. Adv Enzymol Relat Areas Mol Biol, 63 (1990), pp. (421-449).

Thurnham, D.I.; McCabe, L.D.; Haldar, S.; Wieringa, F.T.; Northrop-Clewes, C.A. \& McCabe, G.P. (2010). Adjusting plasma ferritin concentrations to remove the effects of subclinical inflammation in the assessment of iron deficiency: a meta-analysis. Am J Clin Nutr, 92(3) (2010), pp. (546-555).

Tilg, H.; Dinarello, C.A. \& Mier, J.W. (1997). Il-6 and APPs: Anti-inflammatory and immunosuppressive mediators. Immunol Today, 18 (1997), pp. (428-432).

Torrance, J.D.; Charlton, R.W.; Simon, M.O.; Lynch, S.R. \& Bothwell, T.H. (1978). The mechanism of endotoxin-induced hypoferremia. Scand J Haematol, 21 (1978), pp. (403-410).

Torti, S.V. \& Torti, F.M. (1994). Iron and ferritin in inflammation and cancer. Adv Inorg Biochem, 10 (1994), pp. (119-137). 
Torti, F.M. \& Torti, S.V. (2002). Regulation of ferritin genes and protein. Blood, 99(10) (2002), pp. (3505-3516).

Tripathi, P.K. \& Chatterjee, S.K. (1996). Elevated expression of ferritin H-chain mRNA in metastatic ovarian tumor. Can Invest, 14(6) (1996), pp. (518-526).

Truty, J.; Malpe, R. \& Linder, M.C. (2001). Iron prevents ferritin turnover in hepatic cells. J Biol Chem, 276(52) (2001), pp. (48775-48780).

Tsuji, Y.; Ayaki, H.; Whitman, S.P.; Morrow, C.S.; Torti, S.V. \& Torti, F.M. (2000). Coordinate transcriptional and translational regulation of ferritin in response to oxidative stress. Mol Cell Biol, 20(16) (2000), pp. (5818-5827).

Turkson, J. \& Jove, R. (2000). STAT proteins: novel molecular targets for cancer drug discovery. Oncogene, 19(56) (2000), pp. (6613-6626).

Vardhan, H.; Bhengraj, A.R.; Jha, R.; Srivastava, P.; Jha, H.C. \& Mittal, A. (2010). Higher expression of ferritin protects Chlamydia trachomatis infected HeLa 229 cells from reactive oxygen species mediated cell death. Biochem Cell Biol, 88(5) (2010), pp. (835842).

Vernet, M.; Renversez, J.C.; Lasne, Y.; Revenant, M.C.; Charlier de Bressing, C.; Guillemin, C.; Pressac, M. \& Rymer, J.C. (1995). Comparison of six serum ferritin immunoassays and isoferritin spectrotypes in malignancies. Ann Biol Clin, 53 (1995), pp. (419-427).

Wagstaff, M.; Worwood, M. \& Jacobs, A. (1982). Iron and isoferritins in iron overload. Clin Sci, 62(5) (1982), pp. (529-540).

Wang, W.; Knovich, M.A.; Coffman, L.G.; Torti, F.M. \& Torti, S.V. (2010). Serum ferritin: past, present and future. Biochim Biophys Acta, 1800 (2010), pp. (760-769).

Watt, G.D.; Frankel, R.B. \& Papaefthymiou, G.C. (1985). Reduction of mammalian ferritin. Proc Natl Acad Sci USA, 82 (1985), pp. (3640-3643).

Weinstein, R.E.; Bond, B.H. \& Silberberg, B.K. (1982). Tissue ferritin concentrations in cancinoma of the breast. Cancer, 50(11) (1982), pp. (2406-2409).

Weir, M.P.; Sharp, G.A. \& Peters, T.J. (1985). Electron microscopic studies of human haemosiderin and ferritin. J Clin Pathol, 38 (1985), pp. (915-918).

Weiss, G. \& Goodnough, L.T. (2005). Anemia of chronic disease. New Engl J Med, 352(10) (2005), pp. (1011-1023).

White, K. \& Munro, H.N. (1988). Induction of ferritin subunit synthesis by iron is regulated at both the transcriptional and translational levels. J Biol Chem, 263(18) (1988), pp. (8938-8942).

Whittaker, D.; Torrance, J.D. \& Kew, M.C. (1984). Isolation of ferritin from human hepatocellular carcinoma. Scand J Haematol, 33(5) (1984), pp. (432-439).

Wilkinson IV, J.; Di, X., Schönig, K.; Buss, J.L.; Kock, N.D.; Cline, J.M.; Saunders, T.L.; Bujard, H.; Torti, S.V. \& Torti, F.M. (2006). Tissue-specific expression of ferritin H regulates cellular iron homeostasis in vivo. Biochem J, 395 (2006), pp. (501-507).

Wixom, R.L.; Prutkin, L. \& Munro, H.N. (1980). Hemosiderin: nature, formation, and significance. Int Rev Exp Pathol, 22 (1980), pp. (193-225).

World Health Organization, Centers for Disease Control and Prevention. Assessing the iron status of populations. Geneva, Switzerland, WHO Press, 2004.

World Health Organization, Centers for Disease Control and Prevention. Assessing the iron status of populations. Geneva, Switzerland, WHO Press, 2007. 
Worwood, M.; Dawkins, S.; Wagstaff, M. \& Jacobs, A. (1976). The purification and properties of ferritin from human serum. Biochem J, 157 (1976), pp. (97-103).

Worwood, M. (1982). Ferritin in human tissues and serum. Clin Haematol, 11(2) (1982), pp. (275-307).

Worwood, M. (1990). Ferritin. Blood Rev, 4 (1990), pp. (259-269).

Wu, K.J.; Polack, A. \& Dalla-Favera, R. (1999). Coordinated regulation of iron-controlling genes, H-ferritin and IRP-2, by c-MYC. Sci, 283(5402) (1999), pp. (676-679).

Wu, T.; Sempos, C.T.; Freudenheim, J.L.; Muti, P. \& Smit, E. (2004). Serum iron, copper and zinc concentrations and risk of cancer mortality in US adults. Ann Epidemiol, 14 (2004), pp. (195-201).

Xie, C.; Zhang, N.; Zhou, H.; Li, J.; Li, Q.; Zarubin, T.; Lin, S.C. \& Han, J. (2005). Distinct roles of basal steady-state and induced $\mathrm{H}$-ferritin in tumor necrosis factor-induced death in L929 cells. Mol Cell Biol, 25(15) (2005), pp. (6673-6681).

Yang, D.; Elner, S.G.; Bian, Z.M.; Till, G.O.; Petty, H.R. \& Elner, V.M. (2007). Proinflammatory cytokines increase reactive oxygen species through mitochondria and NADPH oxidase in cultured RPE cells. Exp Eye Res, 85(4) (2007), pp. (462-472).

Yang, D.C.; Wang, F.; Elliott, R.L. \& Head, J.F. (2001). Expression of transferrin receptor and ferritin H-chain mRNA are associated with clinical and histopathological prognostic indicators in breast cancer. Anticancer Res, 21(1B) (2001), pp. (541-549).

Zhang, K-H.; Tian, H-Y.; Gao, X.; Lei, W-W.; Hu, Y.; Wang, D-M.; Pan, X-C.; Yu, M-L. Xu, GJ.; Zhao, F-K. \& Song, J-G. (2009). Ferritin heavy chain-mediated iron homeostasis and subsequent increase in reactive oxygen species production are essential for epithelial-mesenchymal transition. Cancer Res, 69(13) (2009), pp. (5340-5348).

Zhang, Y.; Mikhael, M.; Xu, D.; Li, Y.; Soe-Lin, S.; Ning, B.; Li, W.; Nie, G.; Zhao, Y. \& Ponka, P. (2010). Lysosomal proteolysis is the primary degradation pathway for cytosolic ferritin and cytosolic ferritin degradation is necessary for iron exit. Antioxid Redox Sign, 13(7) (2010), pp. (999-1009).

Zhao, G.; Arosio, P. \& Chasteen, N.D. (2006). Iron(II) and hydrogen peroxide detoxification by human H-chain ferritin. An EPR spin-trapping study. Biochem, 45(10) (2006), pp. (3429-3436). 


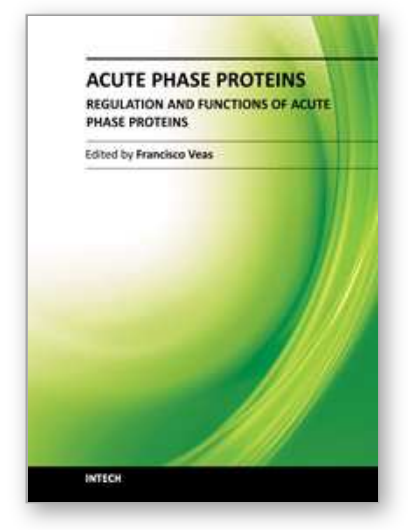

\section{Acute Phase Proteins - Regulation and Functions of Acute Phase Proteins}

Edited by Prof. Francisco Veas

ISBN 978-953-307-252-4

Hard cover, 368 pages

Publisher InTech

Published online 03, October, 2011

Published in print edition October, 2011

The two volumes of Acute Phase Proteins book consist of chapters that give a large panel of fundamental and applied knowledge on one of the major elements of the inflammatory process during the acute phase response, i.e., the acute phase proteins expression and functions that regulate homeostasis. We have organized this book in two volumes - the first volume, mainly containing chapters on structure, biology and functions of APP, the second volume discussing different uses of APP as diagnostic tools in human and veterinary medicine.

\section{How to reference}

In order to correctly reference this scholarly work, feel free to copy and paste the following:

Alida Maria Koorts and Margaretha Viljoen (2011). Acute Phase Proteins: Ferritin and Ferritin Isoforms, Acute Phase Proteins - Regulation and Functions of Acute Phase Proteins, Prof. Francisco Veas (Ed.), ISBN: 978953-307-252-4, InTech, Available from: http://www.intechopen.com/books/acute-phase-proteins-regulationand-functions-of-acute-phase-proteins/acute-phase-proteins-ferritin-and-ferritin-isoforms

\section{INTECH}

open science | open minds

\section{InTech Europe}

University Campus STeP Ri

Slavka Krautzeka 83/A

51000 Rijeka, Croatia

Phone: +385 (51) 770447

Fax: +385 (51) 686166

www.intechopen.com

\section{InTech China}

Unit 405, Office Block, Hotel Equatorial Shanghai

No.65, Yan An Road (West), Shanghai, 200040, China

中国上海市延安西路65号上海国际贵都大饭店办公楼 405 单元

Phone: +86-21-62489820

Fax: +86-21-62489821 
(C) 2011 The Author(s). Licensee IntechOpen. This is an open access article distributed under the terms of the Creative Commons Attribution 3.0 License, which permits unrestricted use, distribution, and reproduction in any medium, provided the original work is properly cited. 